\title{
Ancient Maya Turkey Husbandry: Testing Theories through Stable Isotope Analysis
} Erin Thornton $^{1 *}$, Kitty F. Emery ${ }^{2} \&$ Camilla Speller ${ }^{3}$

\begin{abstract}
Large gaps exist in our knowledge of ancient Maya turkey husbandry and management. Among the questions still needing to be addressed are: 1) when and where was the non-local wild turkey (Meleagris gallopavo) introduced to and adopted by the ancient Maya, and 2) did the ancient Maya also rear captive or tame populations of the indigenous ocellated turkey (Meleagris ocellata)? In this paper, we assess the potential of stable isotope analysis to address these questions. We employ stable carbon $\left(\delta^{13} \mathrm{C}\right)$ and nitrogen $\left(\delta^{15} \mathrm{~N}\right)$ isotope analysis to determine whether wild and husbanded turkeys in the Maya region can be distinguished based on their diets. Strontium isotope analysis $\left({ }^{87} \mathrm{Sr} /{ }^{86} \mathrm{Sr}\right)$ is also used to distinguish between M. gallopavo individuals that were imported from central/northern Mexico, and those raised on-site in the Maya lowlands. The results indicate that stable isotope analysis is a promising and underutilized method for testing theories regarding ancient Maya turkey husbandry.
\end{abstract}

Keywords: animal domestication, Maya, stable isotope analysis, domestic turkey (Meleagris gallopavo), Ocellated Turkey (Meleagris ocellata) 
The Wild Turkey (or common turkey) (Meleagris gallopavo) is the only large-bodied domestic animal used by the pre-colonial Maya besides the dog (Canis lupus familiaris), and the only vertebrate domesticated in Mesoamerica. To better understand how managed or domesticated resources were integrated into ancient Maya subsistence, ritual and political economies, we must first understand the process and extent of Maya turkey husbandry and domestication. The subject is only recently gaining traction in Mesoamerica and the Maya world (Thornton et al 2012; Thornton and Emery, 2015; Lapham et al., this volume; Manin, Cornette and Lefèvre, this volume; Martinez Lira and Valadez, this volume) despite broad interest in the domestic dog in Mesoamerica (Blanco et al. 2006; Götz 2008; Valadez Azúa et al. 2006, 2013), and the domestic turkey in the American Southwest (e.g., Badenhorst et al. 2012; Grimstead et al. 2014; Lipe et al. 2016; McCaffery et al. 2014; McKusick 2001; Munro 2006, 2011; Newbold et al. 2012; Rawlings and Driver 2010; Speller et al. 2010). In Mesoamerica, where the timing of domestication and the possible trade of turkeys are unclear, the lack of osteological markers distinguishing domesticated from wild birds is significantly problematic. Understanding Maya turkey use is complicated by the fact that, in this area, domesticated M. gallopavo is found alongside the local, wild Ocellated Turkey (Meleagris ocellata). Although the latter is not domesticated today, ornithologists and zooarchaeologists have debated whether it too was managed by the pre-Colonial Maya through captive rearing and breeding (Hamblin 1984; Masson and Peraza Lope 2008; Pohl and Feldman 1982; Pollock and Ray 1957; Steadman 1980). Both birds are found in Maya archaeological contexts related to food and ritual, and although they are easily distinguished based on their plumage, distinguishing between them osteologically is extremely difficult especially when dealing with highly fragmented or eroded skeletal remains (Bochensky and Campbell 2006; Emery et al., this issue; Steadman 1980). For this reason, many Maya zooarchaeological studies only identify turkeys to the genus level (Meleagris sp.). Distinguishing domestic, captive-reared and wild individuals within a species 
using zooarchaeological specimens is equally (or even more) problematic (Breitburg 1988, Munro 2006).

In view of the difficulties attendant on morphologically distinguishing the two species of Mesoamerican turkey, and also wild from domesticated/husbanded birds, we assess the potential for stable isotope and ancient DNA analysis to address these issues and elucidate the complex history of ancient Maya turkey husbandry and domestication. Specifically, we employ ancient DNA analysis to taxonomically identify individuals as $M$. gallopavo or $M$. ocellata, stable carbon $\left(\delta^{13} \mathrm{C}\right)$ and nitrogen $\left(\delta^{15} \mathrm{~N}\right)$ isotope analysis to distinguish between wild and husbanded turkeys of either species based on their diets, and strontium isotope analysis $\left({ }^{87} \mathrm{Sr} /{ }^{86} \mathrm{Sr}\right)$ to determine if $M$. gallopavo specimens in the Maya region were imported from central Mexico shortly before death, or raised on-site in the Maya Lowlands, which would indicate early Maya experiments with turkey domestication. Isotopic studies have been used previously to document turkey domestication in the American Southwest (Grimstead et al. 2014; McCaffery et al. 2014; Rawlings and Driver 2010), but similar methods have not yet been widely applied in Mesoamerica.

This paper presents the results of our experimental use of these methods on archaeological turkey specimens from the Maya region. The results indicate that stable isotope analysis is a promising and underutilized method in Mesoamerica for identifying: (1) wild versus captive-reared turkeys, (2) the habitats where wild turkeys were hunted, and (3) whether the earliest domestic turkeys that arrived in the Maya Lowlands were reared on-site or imported from central Mexico. The isotope data also provide comparative data for archaeologists working on similar datasets from the American Southwest and elsewhere (e.g., Morris et al., this issue), and thus contribute to an overall understanding of the history of turkey use, husbandry and domestication in the ancient Americas. 


\section{Mesoamerican Turkeys:}

The South Mexican subspecies of the Wild Turkey (M. g. gallopavo) was first domesticated outside the Maya cultural region in central Mexico (Monteagudo et al. 2013; Speller et al. 2010). The timing of Mesoamerican Wild Turkey domestication is still unclear, but the process of domestication was likely underway by the first half part of the Preclassic or Formative period (1800 BC-AD 250) (Thornton and Emery 2015; Valadez Azúa 2003:74; Valadez Azúa and Arrellín Rosas 2000). Despite the antiquity of turkey husbandry and domestication in northern Mesoamerica, zooarchaeological evidence previously suggested that domestic turkeys were not introduced to or adopted by the ancient Maya until the Postclassic period (AD 1000-1519) (Götz 2008; Hamblin 1984). An earlier introduction, however, is suggested by the recent identification of non-local domestic turkeys at the Late Preclassic (250 BC-AD 250) Maya site of El Mirador located in Petén, Guatemala (Thornton et al. 2012). This finding indicates that some domestic turkeys reached the Maya region several centuries earlier than previously thought, although their widespread adoption and use as a subsistence resource may have occurred much later.

Understanding the adoption and use of domestic turkeys in the Maya region is further complicated by the presence of the indigenous Ocellated Turkey (Meleagis ocellata), which is native to Mexico's Yucatan Peninsula and northern Belize and Guatemala. Although Ocellated Turkeys have never been classified as domesticated, previous research suggests that Postclassic Maya populations reared Ocellated Turkeys in captivity alongside or instead of domestic turkeys at certain sites (Hamblin 1984; Masson and Peraza Lope 2008; Pohl and Feldman 1982; Pollock and Ray 1957). This practice would situate Ocellated Turkeys among a suite of wild taxa that was occasionally managed or reared by ancient Mesoamerican societies, as is still done today (Pohl 1977), including macaws (Ara sp.), parrots (Psittacidae), quail (Colinus sp.) rabbits (Sylvilagus sp.), white-tailed deer (Odocoileus virginianus), peccaries (Tayassuidae) and large 
felids (e.g., Puma concolor, Panthera onca) (Corona Martínez 2002a, 2013; Hamblin 1984;

Lapham, Feinman and Nicholas 2012; Sugiyama, Somerville and Schoeninger 2015; Valadez

Azúa 1993, 2003; White et al. 2004). The extent of these practices is unclear, as is whether the captive animals were maintained for subsistence as well as for elite display and ceremonial purposes, but regardless, Ocellated Turkey husbandry would not be out of place within this cultural framework.

\section{Stable Isotopes and Turkey Domestication}

Because the two species of turkey are so difficult to tease apart osteologically, and because both species may have been reared in captivity or hunted in the wild, we require an alternative method to distinguish wild from managed or husbanded turkeys in Mesoamerica. We argue that stable isotope analysis provides such a tool. We hypothesize that greater maize (Zea mays) consumption by domestic/captive-reared turkeys of either species will distinguish them isotopically from wild turkeys. We also predict that strontium isotopes will provide a means of determining whether the early examples of M. gallopavo in the Maya region represent locally reared animals, or individuals that were imported from their native range in central/northern Mexico shortly before death.

\section{Reconstructing Turkey Diet: Stable Isotope Analysis $\left(\delta^{13} C\right.$ and $\left.\delta^{15} N\right)$}

When animals are brought under human control, their diet changes due to their feeding in a more conscripted region, or the consumption of human provided fodder. These dietary shifts may be studied through stable carbon $\left(\delta^{13} \mathrm{C}\right)$ and nitrogen $\left(\delta^{15} \mathrm{~N}\right)$ isotope analysis since these isotopes serve as proxies for paleodiet (Ambrose and DeNiro 1986, Lee-Thorp, Sealy, and van der Merwe 1989, Schoeninger and DeNiro 1984). Isotopic shifts associated with animal husbandry and domestication have been identified previously for Old World taxa including 
sheep, goats, pigs and cattle (Abarella, Dobney and Rowley-Conwy 2006; Balasse and Ambrose 2005; Makarewicz and Tuross 2012; Minagawa et al. 2005; Noe-Nygarrd et al. 2005), and in Mesoamerican dogs, deer, rabbits, and captive reared predators (Somerville 2015; Sugiyama, Somerville and Schoeninger 2015; Tykot, van der Merwe and Hammond 1996; White et al. 2004). At archaeological sites in the American Southwest, stable isotope analysis has similarly documented rearing of both domestic turkeys (McCaffery et al. 2014; Rawlings and Driver 2010) and captive scarlet macaws (Ara macao) (Somerville, Nelson, and Knudson 2010) based on their extensive consumption of maize (Zea mays).

To date, stable isotopes have not been widely applied to the study of Mesoamerica turkey husbandry, but similar dietary shifts associated with human provided fodder are expected. As in the American SW, maize is the most important agricultural crop grown in Mesoamerica. High maize consumption is detectable in both humans and animals within the region because maize utilizes the $\mathrm{C} 4$ or Hatch-Slack photosynthetic pathway, resulting in higher (less negative) $\delta^{13} \mathrm{C}$ (average $\delta^{13} \mathrm{C}=-12.5 \%$ ) than most other plants including trees, shrubs, root crops and forbs, which utilize the $\mathrm{C} 3$ or Calvin-Benson photosynthetic pathway, (average $\delta^{13} \mathrm{C}=-27 \%$ ) (Smith and Epstein 1971; van der Merwe, 1982). As the agricultural staple, maize was likely provided directly or indirectly (via household waste) to animals raised within human settlements. This is confirmed through ethnographic data (Götz and Garcia Paz, this volume), as well as isotopic evidence for C4-based diets in archaeological Maya dogs and the occasional captive-reared white-tailed deer (White et al. 2001; 2004). Similarly, at the non-Maya site of Teotihuacan in central Mexico, isotopic analysis indicates C4-based diets for captive-reared turkeys (Morales Puente et al. 2012), rabbits (Somerville 2015), eagles, pumas and wolves (Sugiyama, Somerville and Schoeninger 2015). Domestic or captive-reared turkeys in the Maya region are therefore expected to exhibit elevated $\delta^{13} \mathrm{C}$ indicative of significant maize consumption. 
In the wild, both species of Mesoamerican turkey (M. gallopavo and M. ocellata) have a varied, omnivorous diet including fruits, flowers, seeds, nuts, insects, terrestrial gastropods, small lizards, and the leaves of shrubs, forbs and grasses (Hurst 1992; Leopold 1959; Williams, Baur and Eichhoz 2010; Márquez Olivas et al. 2005). The majority of foods consumed by wild turkeys are $\mathrm{C} 3$ plants (e.g., fruits, shrubs, nuts, flowers and some grasses), but they also consume maize when it is available on the landscape (McRoberts 2014; Leopold 1948; Stearns 2010). Other C4 plants potentially consumed include wild or domestic amaranth (Amaranthus sp.), and various species of tropical grasses (e.g., Paspalum congjugatum). Consumption of CAM (Crassulacean Acid Metabolism) plants could also elevate wild turkey $\delta^{13} \mathrm{C}$ (Edwards and Walker 1983). CAM plants available to turkeys include bromeliads and cacti (e.g., Optunia sp., Yucca sp.), but none of these are known to contribute significantly to the diet of wild Mesoamerican turkeys (Baur 2008; Leopold 1959; McRoberts 2014; Márquez Olivas et al. 2005). Although wild foraging turkeys in Mesoamerica may consume C4 and CAM plants that elevate the $\delta^{13} \mathrm{C}$ recorded in their skeletal tissues, the overall expectation is that domestic and captive-reared turkeys will exhibit higher $\delta^{13} \mathrm{C}$ than their wild counterparts due to their greater maize consumption and less varied diet. In contrast, wild turkeys should show diets consisting of pure $\mathrm{C} 3$ or mixed $\mathrm{C} 3 / \mathrm{C} 4$ resources indicative of feeding in forested or mixed forest and agricultural field habitats.

The $\delta^{13} \mathrm{C}$ in Mesoamerican turkeys may also vary due to the "canopy effect". In dense forested environments, ${ }^{13} \mathrm{C}$-depleted carbon dioxide $\left(\mathrm{CO}_{2}\right)$ released through plant respiration is recycled at or near the forest floor, resulting in plant $\delta^{13} \mathrm{C}$ as low as $-35 \%$ in the forest understory (van der Merwe and Medina 1991). Turkeys feed primarily on the ground and obtain much of their food by scratching in leaf litter (Williams, Baur and Eichholz 2010). We would thus expect to observe lower (more negative) $\delta^{13} \mathrm{C}$ in turkeys feeding in forested versus more open or disturbed habitats. Combined with the fact that drier, more open or anthropogenic habitats also 
tend to contain more of the $\mathrm{C} 4$ or CAM plants available to turkeys, this further suggests that $\delta^{13} \mathrm{C}$ in wild turkeys may range from very low in forest-hunted turkeys to intermediate in turkeys feeding primarily along forest edges, or in more open/anthropogenic habitats. In addition to distinguishing between wild and captive turkeys, stable carbon isotope analysis may therefore be able to also identify the habitats where animals were acquired via hunting.

Regardless of habitat, the diverse diet of individual turkeys also may vary according to age, sex and season. For example, poults (0-12 weeks old) ingest large quantities of insects to obtain the protein needed to support early muscle and feather development (Flake et al. 2006). Prior to laying eggs, female turkeys may also consume large quantities of terrestrial snails to build up calcium reserves for egg shell formation (Beasom and Patee 1978). These types of specialized feeding patterns could alter the $\delta^{13} \mathrm{C}$ and $\delta^{15} \mathrm{~N}$ of turkey diets, specifically resulting in elevated $\delta^{15} \mathrm{~N}$ associated with increased animal protein consumption. Bulk bone sample $\delta^{13} \mathrm{C}$ and $\delta^{15} \mathrm{~N}$ represent average dietary intake with slower turnover rates than blood, soft tissues or feathers (Hobson and Clark 1992; Vander Zanden et al. 2015), but the turnover rate in avian bone is poorly documented. Turnover may be as fast as $\sim 200$ days as observed in Japanese quail, or possibly much slower (Hobson and Clark 1992). Turnover rates may also occur at faster rates during sub-adult growth (Hedges et al. 2007; Hobson and Clark 1992), indicating that isotopic values in young birds could preferentially reflect the diet consumed during growth and development.

In contrast, more prolonged or permanent dietary variation between captive and wild turkeys could also result in different $\delta^{15} \mathrm{~N}$ due to variation in relative carnivory or trophic level, consumption of human waste, or rearing conditions that promote protein or water stress. Trophic level effects associated with the transfer of nitrogen up the food chain-result in a 3-4\%o increase with each trophic step from producers to consumers (DeNiro and Epstein 1981; Schoeninger and DeNiro 1984). It is difficult to predict whether wild or captive turkeys would have differed in 
terms of their trophic level, but if such variation existed, it would be observable through $\delta^{15} \mathrm{~N}$. Besides trophic level differences, captive turkeys could have higher $\delta^{15} \mathrm{~N}$ due to the consumption of human feces, which is typically enriched compared to diet by 1.2-3.6\%o (Hwang et al 2007; Sutoh et al. 1987). However, elevated $\delta^{15} \mathrm{~N}$ can also result from heat and nutritional stress (Ambrose 1991:299; Hobson and Clark 1992:195), which could occur in poorly tended captive individuals, or those reared on a very restricted diet. Since many different dietary patterns can alter $\delta^{15} \mathrm{~N}$ in turkeys, nitrogen isotope results should be interpreted with caution.

Despite potential uncertainty in the interpretation of $\delta^{15} \mathrm{~N}$, they have great utility when interpreted in combination with $\delta^{13} \mathrm{C}$ from bone collagen $\left(\delta^{13} \mathrm{C}_{\mathrm{co}}\right)$ and apatite $\left(\delta^{13} \mathrm{C}_{\mathrm{ap}}\right)$. The $\delta^{13} \mathrm{C}$ isotopic composition of dietary protein is preferentially routed to bone collagen, while $\delta^{13} \mathrm{C}_{\mathrm{ap}}$ reflects the isotopic composition of the entire diet including protein, lipids and carbohydrates (Ambrose and Norr 1993, Tieszen and Fagre 1993). In omnivores such as turkeys, the $\delta^{13} \mathrm{C}$ of dietary protein and carbohydrates may diverge, resulting in different average dietary signatures recorded in bone collagen versus bone apatite. The nature of these differences may be investigated through bone collagen and apatite $\delta^{13} \mathrm{C}$ spacing $\left(\Delta^{13} \mathrm{C}_{\mathrm{co}}{ }^{-a p}\right)$ (Ambrose and Norr 1993; Clementz et al. 2009; Lee-Thorp et al. 1989), and more refined models dietary routing developed by Kellner and Schoeninger (2007) and Froehle et al. (2012). For example, comparison of $\delta^{13} \mathrm{C}_{\mathrm{co}}$ and $\delta^{13} \mathrm{C}_{\mathrm{ap}}$ can suggest whether elevated $\delta^{13} \mathrm{C}_{\mathrm{co}}$ in turkeys can be explained by heavy consumption of $\mathrm{C} 4$ plants such as maize, $\mathrm{C} 4$ plant-eating insects, or both. As potential indicators of trophic level, dietary stress, or human waste consumption, $\delta^{15} \mathrm{~N}$ can be used in tandem with $\delta^{13} \mathrm{C}$ to reconstruct past turkey diet.

Identifying Geographic Origins of Turkeys: Strontium Isotope $\left({ }^{87} \mathrm{Sr}{ }^{86} \mathrm{Sr}\right)$ Analysis

To document that the Maya had fully adopted the practice of Mexican turkey husbandry, even at an early stage in their history, it is also necessary to distinguish between M. gallopavo 
imported from northern Mesoamerica shortly before or after death, and those raised on-site in the Maya lowlands. Strontium isotope $\left({ }^{87} \mathrm{Sr} /{ }^{86} \mathrm{Sr}\right)$ analysis provides a method for distinguishing between imported and locally-reared animals. Within Mesoamerica, the method has been used successfully to identify human migration (Buikstra et al. 2003; Price, Manzanilla, and Middleton 2000; Price 2006; Price et al. 2008; Price et al. 2010; White, Price, and Longstaffe 2007; Wright 2005a, 2005b), and animal trade (Thornton 2011). Since turkey domestication and rearing was widespread in northern Mesoamerica by the start of the Classic Period (Thornton and Emery, 2015; Valadez Azúa 2003) small numbers of domestic turkeys could have been imported into the Maya region from central Mexico, along with other trade goods arriving from this area such as green Pachuca obsidian and ceramic vessels (Golitko and Feinman 2015; Sharer 2003).

Strontium isotope ratios can be used to distinguish between turkeys reared in the Maya lowlands and northern Mesoamerica (e.g., the central Mexican highlands) because the two regions have non-overlapping ${ }^{87} \mathrm{Sr} /{ }^{86} \mathrm{Sr}$ based on the underlying geology. The Maya lowlands are underlain by limestone bedrock with strontium values that range from $0.7080-0.7092(\bar{x}$ $=0.7088$ in the northern lowlands of Mexico's Yucatan Peninsula, and from 0.7070-0.7085 $(\bar{x}=0.7077)$ in the southern/central lowlands of Belize and Guatemala (Hodell et al. 2004; Thornton 2011). In contrast, ${ }^{87} \mathrm{Sr} /{ }^{86} \mathrm{Sr}$ in central Mexico range from $0.7046-0.7055$ (Price, Manzanilla, and Middleton 2000; Price et al. 2008; White, Price, and Longstaffe 2007). Although central Mexico, where M. gallopavo is thought to have been first domesticated, is readily distinguishable from the Maya lowlands, similar ${ }^{87} \mathrm{Sr} /{ }^{86} \mathrm{Sr}(0.7038-0.7053)$ are found in the Maya highlands of Guatemala and long the Pacific coast (Hodell et al. 2004; Price et al. 2008). Regardless of whether the exact origin of non-local turkeys can be determined, strontium isotope ratios can indicate whether turkeys were being husbanded onsite in the Maya lowlands, or obtained through long-distance trade with outside regions where they are indigenous. 
The preferred skeletal material for strontium isotope analysis is tooth enamel due to potential problems with diagenesis in bone, which is more porous (Hoppe, Koch, and Furutani 2003, Price et al. 1992, Sillen and Sealy 1995). Testing tooth enamel, however, is not an option for avian specimens. Standard chemical pretreatment procedures may eliminate or reduce potential Sr contamination in bone apatite, but the results of such procedures are not always effective or consistent (Budd et al. 2000; Hoppe, Koch and Furutani 2003). Despite the potential for sample contamination through intrusive $\mathrm{Sr}$, the large difference in ${ }^{87} \mathrm{Sr} /{ }^{86} \mathrm{Sr}$ between the Maya lowlands and the Mexican highlands means that importation from Central Mexico may be detectable even if some level of diagenetic alteration has occurred. Partial replacement of in-situ strontium would result in intermediate ${ }^{87} \mathrm{Sr} /{ }^{86} \mathrm{Sr}$ (Hoppe, Koch and Furutani 2003) falling between those found in the southern Maya lowlands (0.7070-0.7085) and central Mexico (0.7046-0.7055) (Hodell et al. 2004; Price et al. 2010). Thus, in any situation short of complete replacement, importation of turkeys from central Mexico or some other isotopically similar highland area could be detectable.

\section{Materials and Methods}

\section{Study Sites and Samples}

Archaeological turkeys were selected from six lowland Maya sites, which provide both temporal and geographic coverage of the Maya lowlands (Figure 1). El Mirador, located in north-central Petén, Guatemala, represents one of the largest Preclassic centers built within the Maya lowlands. Late Preclassic M. gallopavo specimens identified at El Mirador are currently the oldest known examples of this species within the Maya region (Thornton et al. 2012). The samples were recovered along with other faunal remains between 1980 and 1982 during excavations led by Bruce Dahlin and Ray Matheny, and identified by Thornton and Emery at the 
Florida Museum of Natural History (FLMNH). The turkey bones were associated with Late Preclassic ceramics in well-sealed, undisturbed contexts (Hansen 1990), and AMS radiocarbon ages from animal bones found in close association with the turkey remains confirm that the deposits are Preclassic (cal 327 BC-AD 54) (Thornton et al. 2012).

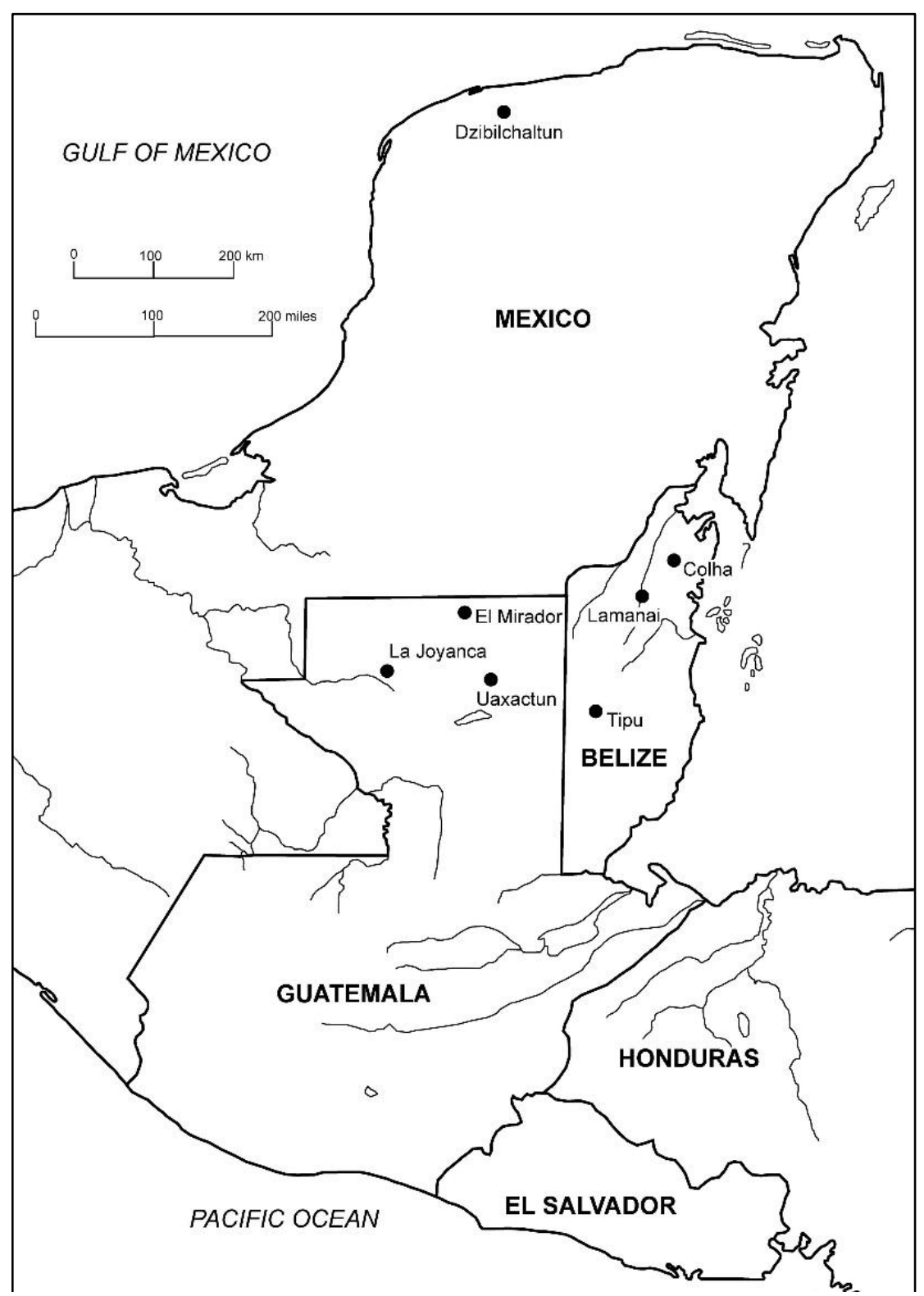

Figure 1: Map of Maya cultural area showing study sites. Map by Thornton. 
The site of La Joyanca is also located in northern Petén, Guatemala, but is situated southwest of El Mirador along the Rio San Pedro Martir. Excavations led by Charlotte Arnauld (Arnauld et al. 2013) indicate that major occupation of the site primarily dates to the Classic Period ( AD 600-950). Identification of the La Joyanca faunal assemblage is in progress at the Florida Museum of Natural History under the supervision of Kitty Emery. Turkey bones selected for use in this study were excavated from two elite patio groups surrounding the site's main plaza.

Turkey samples from the Belizean sites of Lamanai, Tipu and Colha date to the later Postclassic and early Colonial periods (AD 1100-1520+). The fauna from Lamanai and Tipu originate from excavations led by Elizabeth Graham and David Pendergast (Graham 1991; Pendergast 1991), with original zooarchaeological analysis completed by Emery $(1990,1999)$. Faunal remains from both Lamanai and Tipu come from middens and structures located within and around the site's monumental core. Turkey bones from Colha were originally identified and curated by Elizabeth Wing at the Florida Museum of Natural History. The Colha remains originate from excavations at the site led by Norman Hammond (Hammond 1973).

The site of Dzibilchaltun is located in the drier northern Maya lowlands of Mexico's Yucatan Peninsula. Dzibilchaltun has an extremely long occupation history ranging from the Preclassic through the arrival of Spanish conquistadors. The turkey specimens we analyzed were excavated under the direction of E. Wyllys Andrews IV between 1956 and 1966. Original faunal identifications were completed by Elizabeth Wing and David Steadman at FLMNH (Wing and Steadman 1980:327). Turkey bones in our sample were excavated within the site's monumental core and include specimens recovered from Postclassic middens, two Late/Terminal Classic tombs, the 40m deep Cenote Xlacah, and unstratified contexts of unknown date. Bones recovered from the bottom of the ritual cenote are difficult to date securely, but they were found in 
association with artifacts dating to the Late and Terminal Classic (Wing and Steadman 1980:326).

For each site, we controlled for sampling multiple bones from the same individual by restricting our sample whenever possible to a single skeletal element from a particular side of the body (e.g., all right tarsometatarsi). When skeletal elements were non-repeating at a site, we relied on element age and size comparisons, and selection of samples from temporally or spatially discrete proveniences. Although there is potential for food sharing across contemporary contexts, and transport of bones before or after primary deposition, we feel that extensive scattering of a single turkey carcass is unlikely, and that our age and size comparisons prevented redundant sampling of single individuals.

Age assessments were based on categories outlined by McCusick (1986:19). Sub-adult turkeys ( $<12$ months) of both species were included in the sample to assess potential age-related dietary differences that could potentially confound species distinctions. A confounding factor in this study, however, is our inability to assign age classes to all specimens, and to accurately distinguish young adult (12-24 months) from adult (>24 months) turkeys. Age assessments were primarily limited by taphonomic factors such as specimen fragmentation and erosion.

Fifteen modern Ocellated Turkeys hunted near the modern community of Uaxactun, Petén, Guatemala were also sampled to provide baseline data for wild turkey diet. The sample included both male and female individuals collected by Erick Baur (a specialist in the modern galliforms and particularly the Ocellated Turkey) as part of a community-based sustainable hunting program within the Maya Biosphere Reserve (Baur et al. 2012; Williams, Baur and Eichholz 2010) and curated at the Florida Museum of Natural History. The area of capture is composed of a mixture of secondary or regenerating forest, and swidden agricultural fields. Turkeys were hunted $3-33 \mathrm{~km}$ from human settlements in forested, disturbed and agricultural 
habitats. All modern birds were clearly identified as Ocellated Turkeys by Baur based on external morphology while alive, and shortly following death.

\section{Taxonomic Identification of Archaeological Specimens via Ancient DNA}

All archaeological turkey specimens in this study were identified through ancient DNA (aDNA) analysis given the difficulties of identification using osteology (see Emery et al., this volume) to ensure that our tests of isotopic data were linked to accurate identifications. Genetic analyses of the archaeological turkey specimen were conducted in the dedicated ancient DNA Laboratory at the University of York following strict contamination control protocols. A section of turkey bone was removed using a sterilized saw blade. The sub-sample was rinsed in HPLC water, irradiated under UV light for 30 minutes on two sides, and ground into powder. Approximately 50-150mg of bone powder was combined with $1 \mathrm{ml}$ lysis buffer (0.5M EDTA, $\mathrm{pH} 8.0,0.5 \mathrm{mg} / \mathrm{ml}$ proteinase $\mathrm{K}$ ) and incubated overnight at $37^{\circ} \mathrm{C}$. Following the protocol recommended in Gamba et al. (2015), the partially digested bone sample was centrifuged to consolidate the pellet and the supernatant removed; an additional $1.5 \mathrm{ml}$ of lysis buffer was added to the remaining pellet, and incubated for two days at $50^{\circ} \mathrm{C}$ until the pellet was completely demineralized. DNA extraction used only the supernatant from the second digestion followed a silica-spin column method proposed in Yang et al. (1998) as modified in Speller et al. (2010), with DNA eluted in 50ul of EB buffer. PCR amplifications targeted a 139bp fragment of the turkey mtDNA D-loop using published primers TK-F205/TK-R405 (Thornton et al. 2012) with PCR reactions and annealing conditions as described in Speller et al. 2010. This region is ideal for species identification as there are over 15 single nucleotide polymorphisms (SNPs) distinguishing the two species within a relatively short locus. Successfully amplified PCR products were sequenced using forward and/or reverse primers at Eurofins Genomics. Obtained sequences were edited and primer sequences removed using Chromas Pro (http://technelysium.com.au/), and multiple alignments were conducted through BioEdit (Hall, 
1999). Following the removal of primer sequences, sequence were assigned to either $M$.

gallopavo or M. ocellata through multiple alignments with reference sequences obtained through GenBank.

\section{Stable Isotope Analysis of Archaeological and Modern Specimens}

Sample preparation and isotopic analysis was conducted at the University of Florida in laboratory facilities house in the Departments of Anthropology and Geological Sciences. Bone collagen and apatite samples were prepared using standard procedures (Ambrose 1990; Koch et al. 1997) with slight modifications. Bone samples were manually cleaned and sonicated in distilled water to remove visible dirt and debris. After cleaning, archaeological bone samples were gently crushed with a mortar and pestle. Modern bone samples were resistant to manual breakage and were therefore ground using a Spex 6700 freezer/mill. Lipids were also removed from modern bone samples using a Dionex Accelerated Solvent Extractor (ASE). Samples were infused with petroleum ether, heated to $100^{\circ} \mathrm{C}$, soaked for $5 \mathrm{~min}$, rinsed, and dried with compressed nitrogen. The removal of lipids from modern samples was a necessary because residual lipids may skew bone collagen $\delta^{13} \mathrm{C}$ by up to 7\%o (Evershed et al. 1995; Liden et al. 1995). Archaeological samples were not subjected to lipid treatment because lipids are largely absent or highly degraded in ancient samples.

Bone collagen was obtained by demineralizing $\sim 0.25-0.5 \mathrm{~g}$ of crushed cortical bone in 0.2M hydrochloric acid $(\mathrm{HCl})$, followed by treatment with $0.125 \mathrm{M}$ sodium hydroxide $(\mathrm{NaOH})$ to remove organic contaminants. Samples were then solubilized with $10^{-3} \mathrm{M} \mathrm{HCl}$ at $90^{\circ} \mathrm{C}$ and centrifuged to remove particulate contaminants. Bone apatite was obtained by soaking $\sim 0.05 \mathrm{~g}$ of finely crushed cortical bone in a $2 \%$ sodium hypochlorite $(\mathrm{NaClO})$ solution for 16 hours to dissolve sample organics. After being rinsed to neutral, non-biogenic carbonates were removed by soaking the samples for four hours in $0.1 \mathrm{M}$ acetic acid $\left(\mathrm{C}_{2} \mathrm{H}_{4} \mathrm{O}_{2}\right)$. 
Stable isotope ratios were measured on a Finnigan-MAT DeltaPlus isotope ratio mass spectrometer. All collagen samples were also combusted in a Carlo Erba NA1500 CNS elemental analyzer to obtain $\mathrm{C} / \mathrm{N}$ ratios as a measure of sample integrity (Ambrose 1990). To maintain analytical accuracy, isotope data were accepted only when $\mathrm{C} / \mathrm{N}$ ratios fell between 2.8 and 3.8 (Ambrose and DeNiro 1986) and when yield was greater than $1 \%$ of dry weight. Carbon ratios preserved in bone apatite were analyzed on a Micromass PRISM Series II isotope ratio mass spectrometer. Accuracy of $\delta^{13} \mathrm{C}$ and $\delta^{15} \mathrm{~N}$ were confirmed through repeated $(\mathrm{n}>10)$ analysis of international laboratory standards (NBS-19 and USGS-40). Reproducibility was better than $\pm 0.2 \%$ for $\delta^{13} \mathrm{C}_{\mathrm{ap}}, \delta^{13} \mathrm{C}_{\text {coll }}$ and $\delta^{15} \mathrm{~N}$.

Stable isotope ratios for carbon and nitrogen are reported in delta notation $(\delta)$ as parts per thousand (\%o, per mil) which constitutes the difference of the sample from a standard reference material as outlined in the following equation:

$$
\delta(\%)=\left[\left(R_{\text {sample }}\right) /\left(R_{\text {standard }}\right)-1\right] \times 1000
$$

where $\mathrm{R}$ is the ratio of the heavier isotope to the lighter isotope. The established standard for stable carbon isotope ratios $\left(\delta^{13} \mathrm{C}\right)$ is Vienna Pee Dee Belemnite (v-PDB) and for stable nitrogen isotope ratios $\left(\delta^{15} \mathrm{~N}\right)$ is atmospheric air (AIR). All modern $\delta^{13} \mathrm{C}$ are reported with a $+1.5 \%$ correction factor to account for modern enrichment of atmospheric ${ }^{12} \mathrm{C}$ caused by the burning of fossil fuels (Friedli et al. 1986; Marino and McElroy 1991). By adjusting the modern samples by $+1.5 \%$, modern values are directly comparable to those obtained from archaeological samples.

Bones selected for strontium isotope analysis were cleaned and subsampled using a finetipped dental drill. Sample pretreatment and strontium isolation was then conducted in a class 1000 clean lab. Samples were pretreated for 30 minutes in a 5\% acetic acid solution to remove post-depositional contaminants and rinsed to neutral with $4 \mathrm{x}$ distilled water. This method is generally considered to be an effective means of removing contaminants (e.g., Nielsen-Marsh and Hedges 2000; Price et al. 1992; Sillen and Sealy 1995). After pretreatment, the samples were 
transferred to sterile Teflon beakers and hot-digested in $3 \mathrm{ml}$ of $50 \%$ nitric acid $\left(\mathrm{HNO}_{3}\right.$ optima).

Samples were then loaded into cation exchange columns packed with strontium-selective crown ether resin to isolate strontium from other ions. Sample ${ }^{87} \mathrm{Sr} /{ }^{86} \mathrm{Sr}$ was measured with at Micromass Sector 54 thermal ionization mass spectrometer (TIMS). Multiple samples of the strontium standard NBS-987 were run to confirm instrument accuracy. External precision of analysis was \pm 0.00002 (2 sigma absolute) based on 314 analyses of NBS-987. Strontium isotope ratios are reported as an absolute value against the established standard NBS-987. Strontium isotope analysis was only applied to the three Late Preclassic turkeys from El Mirador that current pre-date most other examples of this species in the Maya lowlands (Thornton et al. 2012; Thornton and Emery 2015).

\section{Results and Discussion}

\section{Carbon and Nitrogen Isotopes: Species Diet Comparisons}

All 40 archaeological specimens successfully identified to the species level via aDNA yielded enough collagen for testing, and acceptable $\mathrm{C}: \mathrm{N}$ ratios ranging from 3.2-3.4 (Table 1). In all but two samples (\#2697, 3184) morphological identifications were consistent with the aDNA results. Based on the aDNA identifications, the isotopic sample is composed of $27 \mathrm{M}$. gallopavo and $13 \mathrm{M}$. ocellata archaeological specimens ${ }^{1}$, for a total assemblage of 55 birds including the modern M. ocellata.

Isotope data for our tests of 15 modern Ocellated Turkeys reflect typical C3-based terrestrial diets (average $\delta^{13} \mathrm{C}_{\mathrm{co}}=-20.2 \%$; average $\delta^{15} \mathrm{~N}=5.8 \%$ ) (Table 1, Figure 2). Slightly higher $\delta^{13} \mathrm{C}_{\mathrm{co}}$ are observed in modern Ocellated Turkeys hunted in agricultural, heavily disturbed (regenerating), and scrub habitats $\left(n=7\right.$, avg. $\left.\delta^{13} C_{c o}=-19.95\right)$ than in forested areas $(n=8$, avg.

\footnotetext{
${ }^{1}$ The 40 archaeological specimens with successful DNA identifications were selected from a larger dataset which included multiple failed PCR amplifications. The overall success rate for DNA amplifications from the assemblage as a whole was $\sim 75 \%$.
} 
$\delta^{13} \mathrm{C}_{\mathrm{co}}=-20.33$ ), but the difference was not statistically significant (Student's t-test: $\mathrm{t}(8)=2.31$, $\mathrm{p}=0.32$ ). Thus we can state that, even in areas near human settlements and agricultural fields, wild turkeys in the Maya lowlands consume a diet consisting of primarily $\mathrm{C} 3$ resources.

The archaeological Ocellated Turkeys of this test exhibited significantly higher average $\delta^{13} \mathrm{C}_{\mathrm{co}}$ (avg.: $-18.1 \%$; Student's t-test: $\left.\mathrm{t}(13)=2.16, \mathrm{p}<0.05\right)$ than the modern Ocellated Turkeys (Table 1, Figure 2). The difference in mean $\delta^{13} \mathrm{C}_{\mathrm{co}}$ primarily results from the greater upper range of values observed in the archaeological sample $\left(\delta^{13} \mathrm{C}_{\mathrm{co}}\right.$ : -13.3 to $\left.-22.7 \%\right)$. While eight of the archaeological Ocellated Turkeys consumed predominantly C3-based diets similar to modern Ocellated Turkeys, five archaeological specimens have intermediate $\delta^{13} \mathrm{C}_{\mathrm{co}}(-17$ to $-13 \%$ ) indicative of a mixed diet containing both $\mathrm{C} 3$ and $\mathrm{C} 4$ resources. This pattern is also observable in $\delta^{13} \mathrm{C}$ obtained from bone apatite $\left(\delta^{13} \mathrm{C}_{\mathrm{ap}}\right)$ (Figure 3$)$ although the results are considered less reliable than $\delta^{13} \mathrm{C}$ from bone collagen due to greater potential for diagenesis (Lee-Thorp and Sponheimer 2003). The archaeological Ocellated Turkeys with elevated $\delta^{13} \mathrm{C}_{\mathrm{co}}$ and $\delta^{13} \mathrm{C}_{\mathrm{ap}}$ are not restricted to any particular site or region, and instead occur alongside Ocellated Turkeys with C3-based diets. This suggests that elevated $\delta^{13} \mathrm{C}$ does not result simply from natural regional variation in vegetation between the wetter southern and drier northern Maya Lowlands, and instead reflect differences in individual turkey diet. The archaeological Ocellated Turkey specimens also exhibit greater variation in $\delta^{15} \mathrm{~N}$ than their modern counterparts, but the difference is not statistically significant (Student's t-test: $\mathrm{t}(15)=2.13, \mathrm{p}=0.35$ ) (Table 1, Figure 2). 
Table 1: Stable isotope data from archaeological and modern turkeys from the Maya region

\begin{tabular}{|c|c|c|c|c|c|c|c|c|c|c|c|c|c|}
\hline Lab \# & Site & $\begin{array}{l}\text { Chronology or } \\
\text { Location }\end{array}$ & $\begin{array}{l}\text { Age } \\
\text { (months) }\end{array}$ & Element & $\begin{array}{l}\delta^{13} C_{a p} \\
(\% o)^{a}\end{array}$ & $\begin{array}{l}\delta^{13} \mathrm{C}_{\mathrm{co}} \\
(\% \circ)^{\mathrm{a}}\end{array}$ & $\begin{array}{l}\delta^{15} \mathrm{~N} \\
(\% \circ)\end{array}$ & $\begin{array}{l}\mathrm{Wt} \\
\% \mathrm{C}\end{array}$ & $\begin{array}{l}\mathrm{Wt} \\
\% \mathrm{~N}\end{array}$ & $\mathrm{C}: \mathrm{N}$ & $\begin{array}{c}\text { Collagen } \\
\text { yield } \\
(\% w t)\end{array}$ & ${ }^{87} \mathrm{Sr} /{ }^{86} \mathrm{Sr}$ & $\begin{array}{l}\text { mtDNA } \\
\text { identif. }^{b}\end{array}$ \\
\hline \multicolumn{14}{|c|}{ Archaeological (M. gallopavo): } \\
\hline 2696 & El Mirador & Late Preclassic & 12 mos. & tarsometa. & -3.8 & -10.9 & 9.1 & 32.2 & 11.0 & 3.4 & 2.4 & 0.70792 & $-{ }^{b}$ \\
\hline 2701 & El Mirador & Late Preclassic & - & ulna & -3.9 & -10.4 & 7.9 & 36.1 & 12.7 & 3.3 & 3.1 & 0.70790 & $-{ }^{b}$ \\
\hline 2702 & El Mirador & Late Preclassic & $12+$ mos. & ulna & -6.2 & -14.0 & 9.5 & 35.0 & 12.2 & 3.3 & 2.1 & 0.70790 & $-{ }^{b}$ \\
\hline 2367 & Dzibilchaltun & No date & - & humerus & -0.6 & -8.7 & 8.6 & 45.0 & 16.0 & 3.3 & 12.5 & - & MG \\
\hline 8 & Dzibilchaltun & No date & - & carpometa. & -1.8 & -8.6 & 8.8 & 43.8 & 16.0 & 3.2 & 13.3 & - & MG \\
\hline 12 & Dzibilchaltun & No date & $12+$ mos. & femur & -2.1 & -10.3 & 9.2 & 42.3 & 15.1 & 3.3 & 10.4 & - & MG \\
\hline $2384^{*}$ & Dzibilchaltun & Postclassic & $3-6$ mos. & femur & -8.1 & -12.7 & 6.3 & 46.4 & 16.3 & 3.3 & 17.8 & - & MG \\
\hline 2400 & Dzibilchaltun & Postclassic & $12+$ mos. & femur & -2.4 & -9.9 & 8.1 & 47.5 & 16.9 & 3.3 & 12.8 & - & MG \\
\hline $71^{*}$ & Lamanai & Postclassic/Colonial & 3-6 mos. & tibiotars. & -6.6 & -8.5 & 7.0 & 37.9 & 13.3 & 3.3 & 2.6 & - & MG \\
\hline 86 & Lamanai & Colonial & $12+$ mos. & tarsometa & -5.0 & -9.3 & 9.4 & 14.2 & 5.0 & 3.3 & 9.9 & - & MG \\
\hline 98 & Lamanai & Colonial & $12+$ mos. & tarsometa & -4.4 & -9.0 & 8.0 & 38.9 & 13.6 & 3.3 & 8.0 & - & MG \\
\hline 122 & Lamanai & Postclassic/Colonial & $12+$ mos. & tarsometa & -5.1 & -8.8 & 7.0 & 36.9 & 13.2 & 3.3 & 3.4 & - & MG \\
\hline 129 & Lamanai & Postclassic/Colonial & 12+ mos. & tarsometa & -5.6 & -8.3 & 6.9 & 39.7 & 14.1 & 3.3 & 9.5 & - & MG \\
\hline 195 & Lamanai & Postclassic/Colonial & 12+ mos. & tarsometa & -5.4 & -8.5 & 9.0 & 38.5 & 13.6 & 3.3 & 11.4 & - & MG \\
\hline 200 & Lamanai & Postclassic/Colonial & $12+$ mos. & tarsometa & -4.8 & -8.3 & 7.8 & 40.4 & 14.4 & 3.3 & 13.8 & - & MG \\
\hline 256 & Lamanai & Postclassic/Colonial & 12+ mos. & tarsometa & -6.1 & -7.5 & 7.1 & 38.2 & 13.3 & 3.4 & 6.9 & - & MG \\
\hline 259 & Lamanai & Postclassic/Colonial & $12+$ mos. & tarsometa & -4.8 & -10.2 & 7.0 & 41.4 & 14.5 & 3.3 & 12.4 & - & MG \\
\hline 2753 & Tipu & Postclassic & - & tarsometa & -4.2 & -8.9 & 6.7 & 41.5 & 14.7 & 3.3 & 18.0 & - & MG \\
\hline 2851 & Tipu & Colonial & $12+$ mos. & tarsometa & -5.1 & -10.3 & 5.9 & 40.3 & 14.0 & 3.4 & 17.4 & - & MG \\
\hline 2853 & Tipu & Colonial & $\sim 9+$ mos. & tarsometa & -4.6 & -8.9 & 6.1 & 39.9 & 13.9 & 3.4 & 18.0 & - & MG \\
\hline 3152 & Tipu & Colonial & $12+$ mos. & tarsometa & -4.4 & -9.5 & 7.3 & 41.2 & 14.5 & 3.3 & 16.4 & - & MG \\
\hline 3184 & Tipu & Colonial & $12+$ mos. & tarsometa & -5.0 & -7.8 & 6.5 & 41.1 & 14.6 & 3.3 & 15.8 & - & MG \\
\hline 2510 & Colha & Postclassic & - & humerus & -3.6 & -8.4 & 7.1 & 40.3 & 14.4 & 3.3 & 13.9 & - & MG \\
\hline $2525^{*}$ & Colha & Postclassic & 3-6 mos. & tibiotars. & -7.8 & -10.7 & 8.6 & 39.5 & 13.6 & 3.4 & 4.3 & - & MG \\
\hline 2529 & Colha & Postclassic & - & ulna & -6.5 & -7.9 & 6.9 & 41.1 & 14.8 & 3.3 & 10.1 & - & MG \\
\hline 2538 & Colha & Postclassic & - & ulna & -5.7 & -8 & 6.4 & 41.2 & 14.7 & 3.3 & 7.9 & - & MG \\
\hline \multirow[t]{2}{*}{2541} & Colha & Postclassic & 12+mos. & coracoid & -6.4 & -7.4 & 7.5 & 41.5 & 14.7 & 3.3 & 6.4 & - & MG \\
\hline & & & & Mean: & -4.8 & -9.3 & 7.6 & & & & & & \\
\hline \multicolumn{14}{|c|}{ Archaeological (M. ocellata): } \\
\hline 2697 & El Mirador & Late Preclassic & - & femur & -12.7 & -20.1 & 6.5 & 41.5 & 14.8 & 3.3 & 20.9 & - & MOC \\
\hline 13 & Dzibilchaltun & Late/Terminal Classic & $12+$ mos. & ulna & -5.8 & -13.6 & 8.4 & 45.2 & 16.1 & 3.3 & 12.6 & - & MOC \\
\hline 2371 & Dzibilchaltun & Terminal Classic & $12+$ mos. & ulna & -12.0 & -20.9 & 9.0 & 43.8 & 15.3 & 3.3 & 14.1 & - & MOC \\
\hline $2388^{*}$ & Dzibilchaltun & Postclassic & 6-11 mos. & coracoid & -13.1 & -22.7 & 8.1 & 48.2 & 17.0 & 3.3 & 19.2 & - & MOC \\
\hline 2381 & Dzibilchaltun & Postclassic & - & tarsometa. & -13.4 & -20.8 & 6.2 & 47.1 & 16.4 & 3.4 & 17.1 & - & MOC \\
\hline $2380 *$ & Dzibilchaltun & Postclassic & 3-5 mos. & coracoid & -10.4 & -18.0 & 6.8 & 47.5 & 16.5 & 3.4 & 16.3 & - & MOC \\
\hline 2402 & Dzibilchaltun & Classic? & $12+$ mos. & humerus & -7.2 & -15.6 & 6.9 & 48.0 & 17.1 & 3.3 & 12.8 & - & MOC \\
\hline 2428 & La Joyanca & Classic & $12+$ mos. & ulna & -12.7 & -17.5 & 5.9 & 42.0 & 14.9 & 3.3 & 12.7 & - & MOC \\
\hline 2433 & La Joyanca & Classic & $12+\operatorname{mos}$ & carpometa. & -13.1 & -19.3 & 3.9 & 39.0 & 13.8 & 3.3 & 9.8 & - & $\mathrm{MOC}$ \\
\hline 2434 & La Joyanca & Classic & - & humerus & -7.3 & -16.8 & 3.8 & 40.4 & 14.6 & 3.2 & 7.3 & - & MOC \\
\hline 450 & Lamanai & Early Postclassic & $12+$ mos. & tarsometa. & -6.4 & -13.3 & 5.8 & 40.3 & 14.2 & 3.3 & 11.0 & - & MOC \\
\hline 458 & Lamanai & Early Postclassic & - & carpometa. & -7.4 & -14.1 & 6.6 & 38.2 & 13.1 & 3.4 & 2.1 & - & MOC \\
\hline \multirow[t]{2}{*}{2757} & Tipu & Postclassic & - & coracoid & -12.1 & -22.6 & 3.8 & 40.6 & 14.6 & 3.3 & 13.5 & - & MOC \\
\hline & & & & Mean: & -10.3 & -18.1 & 6.3 & & & & & & \\
\hline \multicolumn{14}{|c|}{ Modern (M. ocellata $)^{\mathrm{a}, \mathrm{c}}$ : } \\
\hline 41686 & Guatemala & active milpa & $12+$ mos. & tarsometa. & -12.2 & -19.6 & 5.3 & 42.5 & 15.0 & 3.3 & 23.9 & - & - \\
\hline 41667 & Guatemala & regenerating milpa & $12+\operatorname{mos}$ & tarsometa. & -13.7 & -21.1 & 6.4 & 40.8 & 14.4 & 3.3 & 29.4 & 0.70781 & - \\
\hline 41668 & Guatemala & regenerating milpa & $12+$ mos. & tarsometa. & -13.7 & -20.9 & 7.6 & 43.8 & 15.7 & 3.3 & 27.3 & - & - \\
\hline 41674 & Guatemala & regenerating milpa & $12+$ mos. & tarsometa. & -11.2 & -18.8 & 5.8 & 39.3 & 14.1 & 3.2 & 29.0 & 0.70799 & - \\
\hline 41688 & Guatemala & regenerating milpa & $12+$ mos. & tarsometa. & -13.5 & -20.2 & 5.7 & 41.0 & 14.3 & 3.3 & 9.6 & - & - \\
\hline 41719 & Guatemala & regenerating milpa & $12+$ mos. & tarsometa. & -15.0 & -20.1 & 6.3 & 42.0 & 14.7 & 3.3 & 22.4 & - & - \\
\hline 41665 & Guatemala & scrub habitat & 12+ mos. & tarsometa. & -12.2 & -19.1 & 6.3 & 38.3 & 13.8 & 3.2 & 21.1 & 0.70786 & - \\
\hline 41670 & Guatemala & upland forest & $12+$ mos. & tarsometa. & -14.2 & -20.9 & 5.4 & 41.5 & 15.0 & 3.2 & 27.1 & 0.70793 & - \\
\hline 41673 & Guatemala & upland forest & $12+$ mos. & tarsometa. & -12.7 & -20.2 & 5.1 & 42.1 & 15.3 & 3.2 & 26.8 & - & - \\
\hline 41676 & Guatemala & upland forest & $12+$ mos. & tarsometa. & -13.5 & -19.9 & 5.0 & 42.3 & 14.9 & 3.3 & 24.0 & - & - \\
\hline 41696 & Guatemala & upland forest & 12+ mos. & tarsometa. & -14.8 & -20.3 & 5.7 & 41.7 & 14.8 & 3.3 & 23.2 & - & - \\
\hline 41702 & Guatemala & upland forest & 12+ mos. & tarsometa. & -14.3 & -20.3 & 5.3 & 42.5 & 15.0 & 3.3 & 23.9 & - & - \\
\hline 41712 & Guatemala & upland forest & $12+$ mos. & tarsometa. & -12.2 & -20.8 & 5.8 & 42.6 & 15.0 & 3.3 & 24.7 & - & - \\
\hline 41713 & Guatemala & upland forest & $12+$ mos. & tarsometa. & -13.4 & -20.1 & 6.3 & 42.4 & 15.1 & 3.3 & 24.1 & - & - \\
\hline \multirow[t]{2}{*}{41717} & Guatemala & upland forest & 12+ mos. & tarsometa. & -14.1 & -20.2 & 5.1 & 41.4 & 14.6 & 3.3 & 23.3 & - & - \\
\hline & & & & Mean: & -13.4 & -20.2 & 5.8 & & & & & & \\
\hline
\end{tabular}

${ }^{a}$ Modern $\delta^{13} \mathrm{C}$ values have been adjusted by $+1.5 \%$ o to make them comparable to archaeological $\delta^{13} \mathrm{C}$ (Marino and McElroy 1991 )

${ }^{\mathrm{b}} \mathrm{MG}=$ M. gallopavo, $\mathrm{MOC}=$ M. ocellata, - = not tested; El Mirador aDNA identification $(\mathrm{n}=3)$ from Thornton et al. (2012).

${ }^{c}$ Modern sample numbers refer to FLMNH-Ornithology catalog numbers.

* subadult (<12 month of age) 


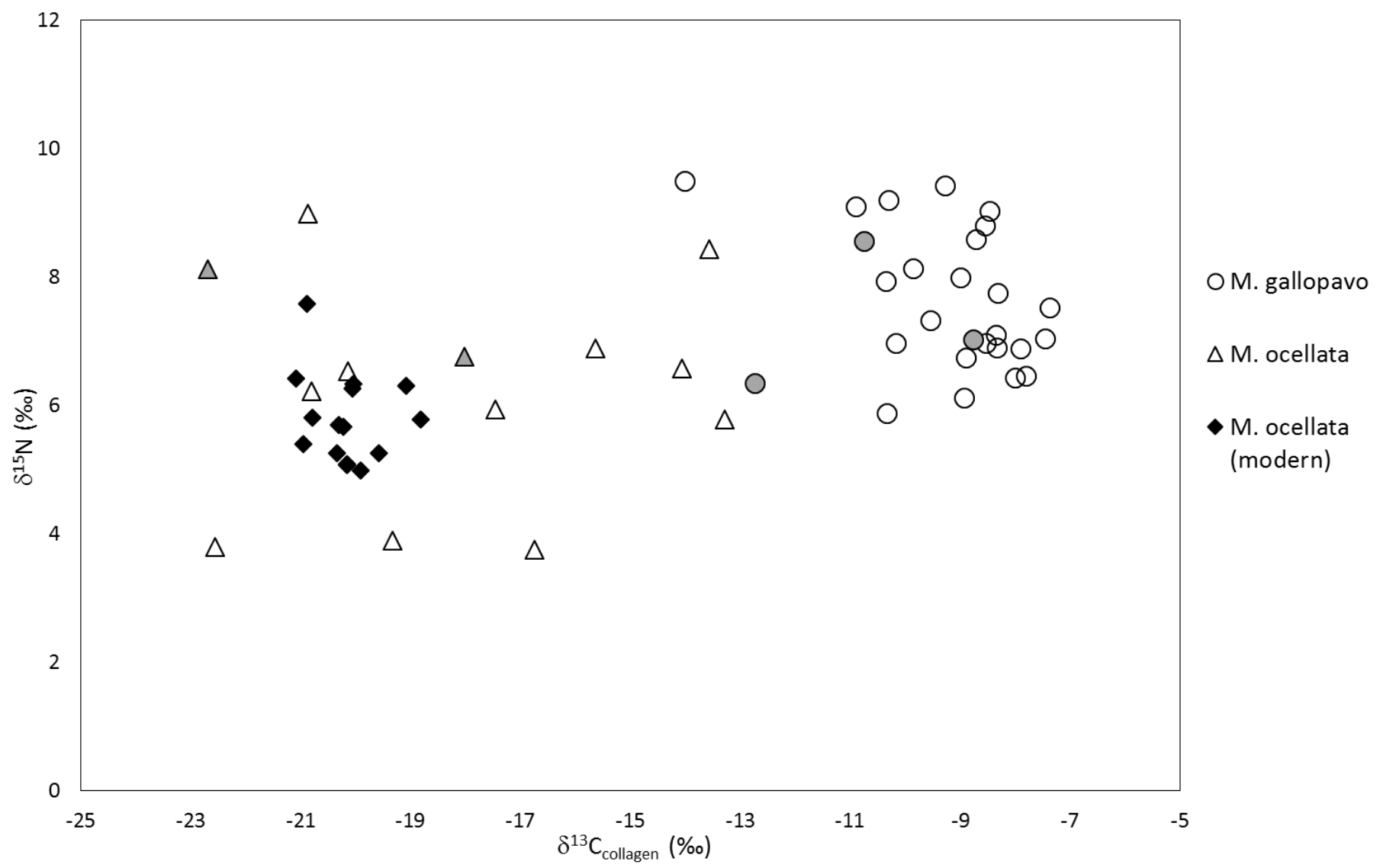

Figure 2: $\delta^{13} \mathrm{C}_{\text {collagen }}$ and $\delta^{15} \mathrm{~N}$ for archaeological (open/gray symbols) and modern (black symbols) turkeys from the Maya region. Gray shading denotes sub-adult archaeological turkeys.

The archaeological M. gallopavo specimens have much higher $\delta^{13} \mathrm{C}_{\mathrm{co}}$ and $\delta^{13} \mathrm{C}_{\mathrm{ap}}$, averaging -9.3 and -4.8\%o, respectively than archaeological M. ocellata (Table 1, Figure 2). These values indicate significant consumption of $\mathrm{C} 4$ foods, which largely distinguishes $M$. gallopavo from both modern and archaeological Ocellated Turkeys. The isotopic separation between the two species, however, is stronger in bone collagen (Figure 2) than it is in bone apatite (Figure 3). Two archaeological M. gallopavo (\#2702, 2384) have lower $\delta^{13} \mathrm{C}_{\mathrm{co}}$ and $\delta^{13} \mathrm{C}_{\mathrm{ap}}$ that approach or partially overlap the highest Ocellated Turkey values, and reflect a more mixed diet of C3 and C4 resources. The M. gallopavo with the lowest $\delta^{13} \mathrm{C}_{\mathrm{co}}$ is an adult $(12+\operatorname{mos}$.) 
turkey from Late Preclassic deposits at El Mirador. The other two contemporary M. gallopavo from the site show elevated $\delta^{13} \mathrm{C}_{\mathrm{co}}$ and $\delta^{13} \mathrm{C}_{\mathrm{ap}}$ indicating greater consumption of $\mathrm{C} 4$ foods. No difference is observed in M. gallopavo from Postclassic versus Colonial contexts, suggesting that potential changes in domestic turkey diet resulting from European Colonialism cannot account for the overall pattern of $\delta^{13} \mathrm{C}$ species separation (Table 2). Instead, domestic turkeys in the Maya lowlands appear to have been maize provisioned from their earlier introduction through Colonial times.

Table 2: Mean Stable Isotope Values of Archaeological Meleagris gallopavo by Time Period

\begin{tabular}{lcccl}
\hline Time Period (\# samples) & $\boldsymbol{\delta}^{13} \mathbf{C}_{\mathrm{ap}}$ & $\boldsymbol{\delta}^{13} \mathrm{C}_{\mathrm{co}}$ & $\boldsymbol{\delta}^{15} \mathbf{N}$ & Sites Included \\
\hline Preclassic $(\mathrm{n}=3)$ & -4.6 & -11.8 & 8.8 & El Mirador \\
Postclassic $(\mathrm{n}=8)$ & -5.6 & -9.2 & 7.2 & Dzibilchaltun, Tipu, Colha \\
Colonial $(\mathrm{n}=6)$ & -4.8 & -9.1 & 7.2 & Lamanai, Tipu \\
\hline
\end{tabular}

All three sub-adult M. gallopavo (Table 1) fall at the lower $\delta^{13} \mathrm{C}_{\text {ap }}$ range for this species (Figure 3), but only one of the sub-adults also has a lower $\delta^{13} \mathrm{C}_{\mathrm{co}}$ that does not cluster as well with the other adult and un-aged $M$. gallopavo (Figure 2). The two sub-adult Ocellated Turkeys (Table 1) do not vary in a consistent pattern from the other $\mathrm{C} 3$ resource eating $M$. ocellata. Average to slightly higher $\delta^{15} \mathrm{~N}$ are observed in the sub-adults of both species, but a consistent age-based pattern is not apparent. Therefore, although age-based dietary differences have the potential to affect individual turkey $\delta^{13} \mathrm{C}$ and $\delta^{15} \mathrm{~N}$, the effect appears to be weak and it does not obscure dietary differences observed between the two species. Our sample size, however, is very small due to our inability to assign age classes to all specimens. The potential for lower $\delta^{13} \mathrm{C}$ in subadult M. gallopavo, especially in bone apatite, warrants further investigation in future studies as this may reflect decreased maize consumption during the periods of early growth and development. For domestic flocks where culling may have occurred shortly after the birds reached adult size (10-12 months old), the potential for age-related isotopic effects could be significant. 


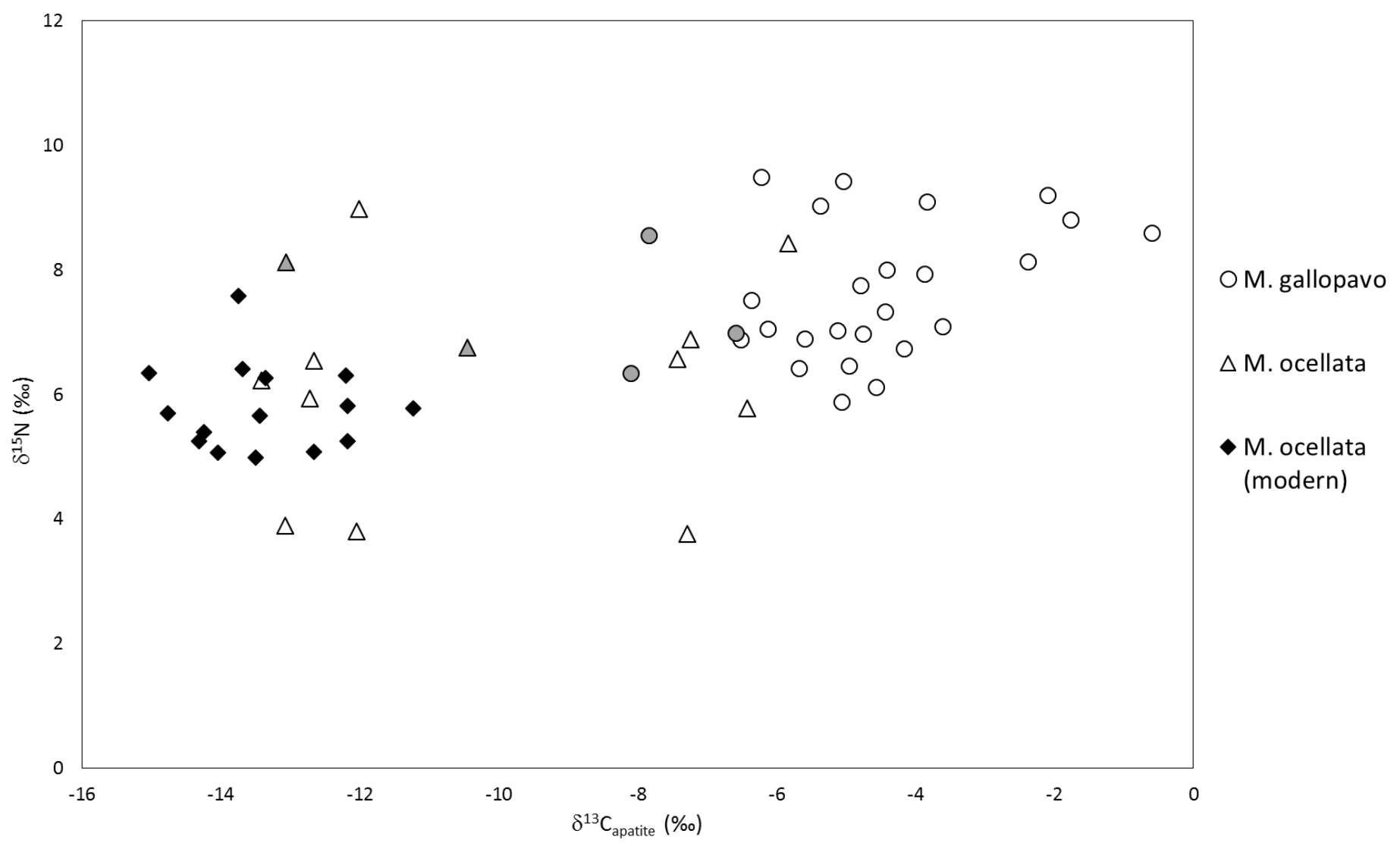

Figure 3: $\delta^{13} \mathrm{C}_{\text {apatite }}$ and $\delta^{15} \mathrm{~N}$ for archaeological (open/gray symbols) and modern (black symbols) turkeys from the Maya region. Gray shading denotes sub-adult archaeological turkeys.

M. ocellata and M. gallopavo overlap to a large extent in their $\delta^{15} \mathrm{~N}$ ranges (Figure 2), but there is a weak positive correlation $\left(\mathrm{r}^{2}=0.52\right)$ between $\delta^{13} \mathrm{C}_{\mathrm{co}}$ and $\delta^{15} \mathrm{~N}$ in the sample, and archaeological $M$. gallopavo have on average significantly higher $\delta^{15} \mathrm{~N}$ than archaeological Ocellated Turkeys (Student's t-test: $\mathrm{t}(19)=2.09, \mathrm{p}<0.05)$ (Table 1$)$. The slightly elevated $\delta^{15} \mathrm{~N}$ in domestic $M$. gallopavo could result from greater consumption of insects or other invertebrates attracted to the anthropogenic environments within and around human settlements. Alternately, they could reflect consumption of household waste, or human or animal feces, which was also potentially common near areas of human habitation and animal rearing.

To further assess the nature and extent of dietary divergence between the two species of Mesoamerican turkeys, we directly compare bone collagen and apatite $\delta^{13} \mathrm{C}$. Within our sample, 
$\delta^{13} \mathrm{C}_{\mathrm{co}}$ and $\delta^{13} \mathrm{C}_{\mathrm{ap}}$ are highly correlated $\left(\mathrm{r}^{2}=0.92 ; 0.86\right.$ archaeological samples only). When plotted against each other (Figure 4), and compared with dietary models generated by Kellner and Schoeninger (2007), it is evident that most M. gallopavo fall towards the upper end of the C4-protein line, indicating primarily $\mathrm{C} 4$ sources for both dietary protein and non-protein. Although other C4 plants cannot be ruled out, it is very likely that domestic turkeys in the Maya Lowlands fed extensively on maize based on modern ethnographic data (Gotz and García Paz, this volume), and evidence of maize consumption in other captive or domestic animals in Mesoamerica (e.g., Sugiyama, Somerville and Schoeninger 2015; Tykot, van der Merwe and Hammond 1996; White et al. 2001). In terms of dietary protein, many of the insects, land snails and small lizards consumed by domestic turkeys may have had elevated $\delta^{13} \mathrm{C}$ based on their feeding within houses, house lots, and nearby middens and latrines which likely contained substantial amounts of the dietary staple maize. Turkeys could also have fed directly on human/animal waste, which is as an additional potential source of C4-based protein. Alternately, higher $\delta^{13} \mathrm{C}_{\mathrm{co}}$ in domestic turkeys could result from a low protein diet. Under typical conditions, bone collagen preferentially reflects the $\delta^{13} \mathrm{C}$ composition of dietary protein, but when animal diets are protein deficient, more carbon from non-protein sources are used for collagen synthesis (Ambrose and Norr 1993). Regardless, the heavier $\delta^{13} \mathrm{C}_{\mathrm{co}}$ of domestic turkeys, either alone or plotted against $\delta^{13} \mathrm{C}_{\mathrm{ap}}$, distinguishes them in most cases from Ocellated Turkeys. 


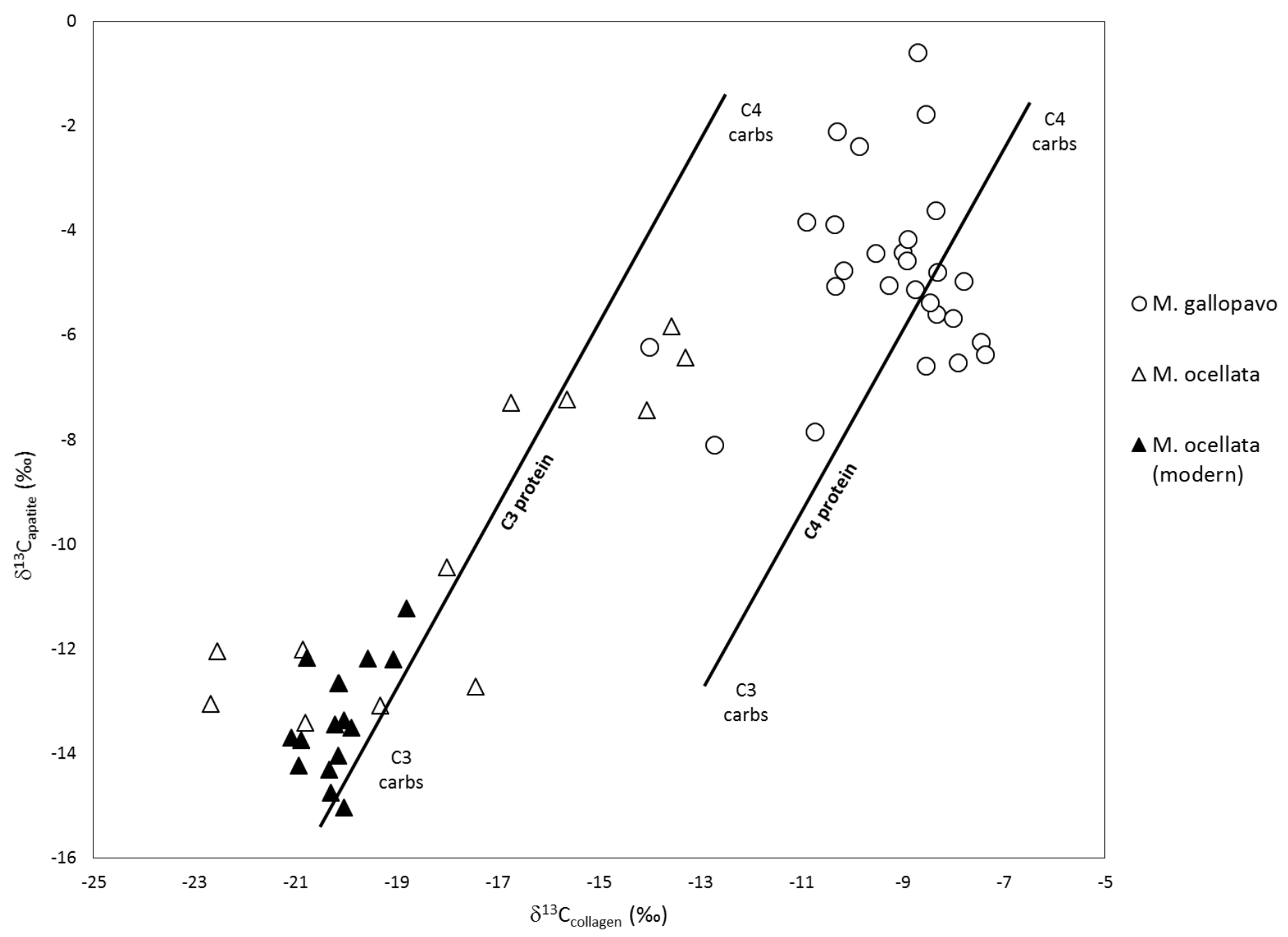

Figure 4: $\delta^{13} \mathrm{C}_{\text {collagen }}$ and $\delta^{13} \mathrm{C}_{\text {apatite }}$ for archaeological (open symbols) and modern (filled symbols) turkeys from the Maya region plotted in comparison to dietary models by Kellner and Schoeninger (2007). 
Comparison of $\delta^{13} \mathrm{C}_{\mathrm{co}}$ and $\delta^{13} \mathrm{C}_{\mathrm{ap}}$ also informs our interpretation of the five archaeological Ocellated Turkeys with intermediate, or elevated $\delta^{13} \mathrm{C}$. These individuals fall either on or slightly closer to the $\mathrm{C} 3$-protein line, indicating that they consumed a mix of $\mathrm{C} 3$ and $\mathrm{C} 4$ plants, but that a larger amount of their protein was C3-based in comparison to domestic turkeys (Figure 4). Although these individuals consumed a substantial amount of C4-plants (likely maize), we would expect their isotopic signatures to overlap more with $M$. gallopavo if they were also bred and reared in captivity from birth alongside domestic turkeys. One possible explanation for the observed pattern is that select Ocellated Turkeys were captured from the wild and reared in captivity for a portion of their lives, resulting in a mid-life dietary shift. Unfortunately, a lack of well-documented turnover or equilibrium rates for bird bone collagen and apatite precludes a determination of how long wild turkeys previously foraging on C3 resources would need to be reared on maize to result in the observed intermediate $\delta^{13} \mathrm{C}$. It would, however, likely take at least a few months for a shift to occur based on known turnover rates in the much smaller-bodied Japanese quail (Hobson and Clark 1992).

An alternate-explanation is that the intermediate group of archaeological Ocellated Turkeys includes wild individuals that fed in forested habitats, as well as in agricultural fields, or on maize bait provided by hunters. Isotopic data from other species including white-tailed deer (Odocoileus virginianus) and peccary (Tayassuidae) in the Maya region support this interpretation. While the majority of deer and peccary from Maya sites have C3-based diets, substantial consumption of $\mathrm{C} 4$ plants has been reported for select individuals with $\delta^{13} \mathrm{C}_{\mathrm{co}}$ ranging from approximately -17.5 to $-7.3 \%$ (Emery, Wright and Schwarcz 2000; Tykot et al. 1996; White et al. 2004; Wright 2006: 192). Although deer and peccary with very high $\delta^{13} \mathrm{C}_{\mathrm{co}}(-13$ to -7 $\%$ ) could indicate captive rearing, the majority of mixed $\mathrm{C} 3 / \mathrm{C} 4$ feeding deer and peccary have only slightly elevated $\delta^{13} \mathrm{C}_{\mathrm{co}}$ ranging from -15 to $-18 \%$, which could result from occasional feeding in maize agricultural fields. We did not observe any birds with intermediate $\delta^{13} \mathrm{C}$ in our 
sample of modern Ocellated Turkeys from Petén, Guatemala, despite the inclusion of individuals that would be classified as garden-hunted (i.e., killed while feeding within and around the edges of active or regenerating agricultural fields). The low $\delta^{13} \mathrm{C}_{\mathrm{co}}$ observed in our modern Ocellated Turkeys may be due to the large amount of forest still present in the region where they were hunted despite the presence of milpas and other anthropogenic habitats. As others have suggested, population levels and the degree of deforestation may have been higher in some regions of the Maya lowlands during ancient times (Cook et al. 2012).

The combined $\delta^{13} \mathrm{C}$ and $\delta^{15} \mathrm{~N}$ results document the utility of stable isotope analysis to identify wild vs. captive-reared and/or domestic turkeys based on dietary differences. Isotopic variation among archaeological Ocellated Turkeys from pure $\mathrm{C} 3$ to mixed $\mathrm{C} 3 / \mathrm{C} 4$ feeders further suggests that the method is able to identify whether wild Ocellated Turkeys were hunted from forested or more open/anthropogenic habitats. Expanded testing along these lines is needed to determine whether the elevated $\delta^{13} \mathrm{C}$ in bone collagen and apatite of Ocellated Turkeys and other common prey species could alternately indicate some degree of human provisioning, management, or confinement.

\section{Strontium Isotopes: Non-local Imports vs. On-site Rearing}

All three M. gallopavo from Late Preclassic deposits at El Mirador yielded ${ }^{87} \mathrm{Sr} /{ }^{86} \mathrm{Sr}$ (0.7078-0.7079) matching those previously reported from archaeological fauna at El Mirador (Thornton 2011). Similar values were also found in our sample of modern Ocellated Turkeys hunted near Uaxactun, Petén, Guatemala (Table 1). Diagenetic tests (e.g., Ca/P ratios, crystallinity indices) have not yet been conducted, but the current results do not support the idea that the non-local M. gallopavo individuals were imported from central Mexico shortly before death. Our results are limited by the fact that complete replacement of the in-situ strontium could result in local values being exhibited in a non-local specimen (Budd et al. 2000), but, in any 
situation short of complete replacement, importation of turkeys from central Mexico or some other isotopically similar highland locale would have been detected. A final caveat is that although we can tentatively conclude that the early M. gallopavo found at El Mirador were reared outside of central Mexico, we cannot rule out their origin from another non-local region within the southern Maya lowlands, or possibly even Oaxaca (Price et al. 2010) that exhibits similar ${ }^{87} \mathrm{Sr} /{ }^{86} \mathrm{Sr}$ to those found at El Mirador.

The potential for sample contamination via diagenesis severely hampers our ability to apply strontium isotope analysis to distinguish between long-distance turkey trade and on-site rearing within the Maya lowlands since bone apatite is the only skeletal tissue available for analysis. Diagenesis tests such as $\mathrm{Ca} / \mathrm{P}$ ratios or crystallinity indices may be employed, but these methods may not detect all sources of diagenetic contamination (Budd et al. 2000). Another potential route may be to conduct multi-proxy isotopic analyses that combine strontium and oxygen $\left(\delta^{18} \mathrm{O}_{\text {phosphate }}\right)$ isotopes. Bone phosphate $\delta^{18} \mathrm{O}$ is more resistant though not impervious to diagenetic alteration (Sharp, Atudorei and Furrer 2000), but the combined proxies would provide stronger evidence than a single data point. The costs of such analyses, and the amount of bone required to run multiple isotopic tests, however, may be prohibitive. Researchers must therefore consider whether generating valuable, but potentially unreliable data is worth the cost of expensive laboratory testing.

\section{Conclusions}

Stable isotope analysis has the potential to yield substantial insights into the history of turkey husbandry and domestication in Mesoamerica. The most promising application is the use of stable carbon and nitrogen isotopes to distinguish between wild and captive-reared/domestic individuals. Morphometric features for such distinctions are often lacking, and both species may have been raised in captivity. Stable isotope analysis thus provides an additional and 
underutilized tool that both complements and expands the capabilities of other currently employed methods including skeletal morphology, osteometrics and aDNA analysis.

The isotope data document that M. gallopavo introduced to the Maya region consumed a diet heavy in $\mathrm{C} 4$ resources, which contrasts with Ocellated turkeys that consumed primarily C3 or mixture of both $\mathrm{C} 3$ and $\mathrm{C} 4$ foods. Isotopic separation between the species likely reflects domestic turkeys' greater access to a C4-based food web within human settlements including human-provided maize fodder, household and human/animal waste, and various invertebrates feeding within the same anthropogenic environment. If further testing confirms isotopic separation of the two species, stable carbon and nitrogen isotopes may be used to distinguish between wild and husbanded turkeys in Maya faunal assemblages. Ancient DNA analysis would still be required to identify the species of turkeys with intermediate $\delta^{13} \mathrm{C}$ and $\delta^{15} \mathrm{~N}$, but stable isotope analysis could serve as a means of identifying and narrowing down the number of individuals that would need to be subjected to costly aDNA analyses.

We also tentatively conclude that the lower and wider range of $\delta^{13} \mathrm{C}_{\text {coll/ap }}$ observed in archaeological Ocellated Turkeys can best be explained by variation in hunting habitat (i.e., forest vs. field) rather than captive rearing of select individuals, but this suggestion requires further investigation. Expanded isotopic testing of archaeological turkeys, and wild modern turkeys from Mesoamerica may be able to resolve this question. Local extirpation of wild turkeys from many parts of Mesoamerica makes it difficult to obtain wild hunted turkeys from a variety of habitats ranging from heavily forested to highly anthropogenic, but modern animals may provide the best evidence for the range of $\delta^{13} \mathrm{C}$ expected in garden-hunted animals. The question of whether Ocellated Turkeys and other prey species such as deer were managed or reared by the ancient Maya is non-trivial as it has major implications for the degree of control ancient populations maintained over their environment and subsistence resources. 
Our strontium isotope analysis of the earliest known introduced $M$. gallopavo in the Maya region suggests that they were reared locally for an extended period of time, rather than being imported from central Mexico shortly before death. This statement is based on a number of assumptions regarding a lack of extensive diagenetic alteration of the samples' original ${ }^{87} \mathrm{Sr} /{ }^{86} \mathrm{Sr}$ signature, and where non-local turkeys likely originated. More testing is required to confirm this statement, but we report the results to support our methodological claim that stable isotope analysis may be the only way to identify whether introduced domestic turkeys represent Maya investment in turkey rearing, or occasional non-local imports. Despite the limitations of this approach, expanded isotopic sourcing of Mesoamerican turkeys may be the only way to address this question.

In sum, this study demonstrates the utility of stable isotope analysis in studying Mesoamerican turkey husbandry, but combined, multi-proxy studies are likely the most powerful methodological approach. Coupled isotopic and aDNA studies provide a means to identify species presence and diet, which is difficult to impossible to determine from morphometric traits alone. Skeletal morphology and metrics, however, provide useful information about the effects of domestication on species biology. Stable isotope analysis of Mesoamerican turkeys should therefore be conducted alongside complementary morphometric, and whenever possible, genetic analyses to generate the most complete record of turkey acquisition, husbandry and use.

\section{Acknowledgements}

We thank John Krigbaum and Ashley Sharpe for coordinating and conducting isotopic analysis of the remains. We are also grateful for the assistance provided by our many collaborators who provided access to specimens including Rani Alexander, Charlotte Arnauld, Jamie Awe, Erick Baur, Arthur Demarest, Antonia Foias, Charles Golden, Chris Götz, Elizabeth Graham, Norman Hammond, Richard Hansen, Gyles Ianonne, Takeshi Inomata, Marilyn Masson, Ray Matheny, 
Carlos Peraza, Andrew Scherer, and Norbert Stanchly. We also thank our graduate students Petra

Cunningham Smith, Lisa Duffy, and Brandon McIntosh who assisted in various stages of the larger project which supported this study. Thanks also to Krista McGrath for technical assistance with the ancient DNA analysis. Funding for our ongoing research on Maya turkey husbandry is provided by the National Science Foundation (BCS-1434289), the Florida Museum of Natural History, University of Florida, and the Washington State University Department of Anthropology.

\section{References Cited}

Albarella, U., Dobney, K., and Rowley-Conwy, P. (2006). The domestication of the pig (Sus scrofa): new challenges and approaches. In Documenting Domestication: New Genetic and Archaeological Paradigms (M.A. Zeder, D.G. Bradley, E. Emshwiller, and B.D. Smith, editors). University of California Press, Berkeley, pp 209-227.

Ambrose, S.H. (1990). Preparation and characterization of bone and tooth collagen for stable carbon and nitrogen isotope analysis. Journal of Archaeological Science 17:430-451.

Ambrose, S.H. (1991). Effects of diet, climate and physiology on nitrogen isotope abundances in terrestrial foodwebs. Journal of Archaeological Science 18:293-317.

Ambrose SH, DeNiro MJ. 1986. The isotopic ecology of East African mammals. Oecologia 69:395-406.

Ambrose, S.H., and Norr, L. (1993). Experimental evidence for the relationship of carbon isotope ratios of whole diet and dietary protein to those of bone collagen and carbonate. In Prehistoric Human Bone: Archaeology at the Molecular Level (J.B. Lambert and G. Gupe, editors). Springer-Verlag, New York, pp. 1-37.

Arnauld, M-C., Lemonnier, E., Forné, M., Galop, D., and Métailié, J-P. (2013). The rise and fall of a secondary polity: La Joyanca (Guatemala). In Millenary Maya Societies: Past Crises and Resilience (M-C. Arnauld and A. Breton, editors). Electronic document, published online at Mesoweb: www.mesoweb.com/publications/MMS/10_Arnauld_etal.pdf.pp. 148-168.

Badenhorst, S., Lyle, R., Merewether, J., Driver, J., and Ryan, S. (2012). The potential of osteometric data for comprehensive studies of turkey (Meleagris gallopavo) husbandry in the American Southwest. KIVA: The Journal of Southwestern Anthropology and History 78:61-78.

Balasse, M. and Ambrose, S.H. (2005). Distinguishing sheep and goats using dental morphology and stable carbon isotopes in C4 grassland environments. Journal of Archaeological Science 32: 691-702. 
Baur, E.H. (2008). Structure of a Lowland Neotropical Galliform Bird Guild. Unpublished MS Thesis, Department of Wildlife Ecology and Conservation, University of Florida, Gainesville.

Baur, E.H., McNab, R.B., Williams, L.E. Jr., Ramos, V.H., Radachowsky, J., Guariguata, M.R. (2012). Multiple forest use through commercial sport hunting: lessons from a community-based model from the Petén, Guatemala. Forest Ecology and Management 268: 112-120.

Beasom, S.L., and Pattee, O.H. (1978). Utilization of snails by Rio Grande turkey hens. The Journal of Wildlife Management 42:916-919.

Blanco, P.A., Rodríguez Galicia, B., Viniegra Rodríguez, F., Olmos Jiménez, J., Mora, C., and Valadez Azúa, R. (2006). Canidos del Templo Mayor de Tenochtitlan. Revista Asociación Mexicana de Médicos Veterinarios Especialistas en Pequeñas Especies 17: 217-226.

Bochenski, Z.M., and Campbell, K.E. (2006). The Extinct California Turkey, Meleagris californica, from Rancho la Brea: Comparative Osteology and Systematics. Los Angeles: Natural History Museum of Los Angeles County.

Breitburg, E. (1988). Prehistoric New World Turkey Domestication. Unpublished Ph.D. Dissertation, Department of Anthropology, Southern Illinois University, Carbondale.

Budd, P., Montgomery, J., Barreiro, B., and Thomas, R.G. (2000). Differential diagénesis of strontium in archaeological human dental tissues. Applied Geochemistry 15: 687-694.

Buikstra, J.D., Price, T.D., Burton, J.H., and Wright, L.E. (2003). Tombs from the Copan acropolis: a life history approach, in: Understanding Early Classic Copan (E. Bell, M. Canuto, and R.J. Sharer, editors). University of Pennsylvania Museum Publications, Philadelphia, pp. 185-206.

Clementz, M.T., Fox-Dobbs, K., Wheatley, P.V., Koch, P.L., and Doak, D.F. (2009). Revisiting old bones: coupled carbon isotope analysis of bioapatite and collagen as an ecological and palaeoecological tool. Geology Journal 44: 605-620.

Cook, B.I., Anchukaitis, K.J., Kaplan, J.O., Puma, M.J., Kelley, M., and Gueyffier, D. (2012). Pre-Columbian deforestation as an amplifier of drought in Mesoamerica. Geophysical Research Letters 39, L16706, doi:10.1029/2012GL052565.

Corona Martínez, E. (2002) Las aves en la historia natural novohispana. Mexico: Instituto Nacional de Antropología e Historia, Mexico City.

Corona Martínez, E. (2013). Birds of the pre-Hispanic domestic sphere of central Mexico. In The Archaeology of Mesoamerican Animals (C.M. Götz, and K.F. Emery, editors). Atlanta: Lockwood Press, Atlanta, pp. 81-94.

DeNiro, MJ, and Epstein, S. (1981). Influence of diet on the distribution of nitrogen isotopes in animals. Geochimica et Cosmochimica Acta 45: 341-351.

Edwards, G., and Walker, D. (1983). C3, C4: Mechanisms and Cellular and Environmental Regulation of Photosynthesis. University of California Press, Berkeley. 
Emery, K.F. (1990). Postclassic and Colonial Period Subsistence Strategies in the Southern Maya Lowlands: Faunal Analyses from Lamanai and Tipu, Beilze. Unpublished M.A. Thesis, Department of Anthropology, University of Toronto.

Emery, K.F. (1999). Continuity and variability in Postclassic and Colonial animal use at Lamanai and Tipu, Belize. In Reconstructing Ancient Maya Diet (C.D. White, editor), University of Utah Press, Salt Lake City, pp. 61-81.

Emery, K.F., Wright, L.E., and Schwarcz, H. (2000). Isotopic analysis of ancient deer bone: biotic stability in Collapse Period Maya land-use. Journal of Archaeological Science 27:537550.

Evershed, R.P., Turner-Walker, G., Hedges, R.E.M., Tuross, N., and Leyden, A. (1995) Preliminary results for the analysis of lipids in ancient bone. Journal of Archaeological Science 22:277-290.

Flake, L.D., Lehman, C.P., Leif, A.P., Rumble, M.A., and Thompson, D.J. (2006). The Wild Turkey in South Dakota. South Dakota State University, Brookings.

Friedli, H., Lötscher, H., Oeschger, H., Siegenthaler, U., and Stauffer, B. (1986). Ice core records of the ${ }^{13} \mathrm{C} /{ }^{12} \mathrm{C}$ ratio of atmospheric $\mathrm{CO}_{2}$ in the past two centuries. Nature 324: 237-238.

Froehle, A.W., Kellner, C.M., and Schoeninger, M.J. (2012). Multivariate Carbon and Nitrogen Stable Isotope Model for the Reconstruction of Prehistoric Human Diet. American Journal of Physical Anthropology 147:352-369.

Gamba, C., Hanghøj, K., Gaunitz, C., Alfarhan, A.H., Alquraishi, S.A., Rasheid, K.A.S. Al-, Bradley, D.G., and Orlando, L. (2015). Comparing the performance of three ancient DNA extraction methods for high-throughput sequencing. Molecular Ecology Resources. doi:10.1111/1755-0998.12470.

Golitko, M., and Feinman, G.M. (2015). Procurement and distribution of Pre-Hispanic Mesoamerican Obsidian 900 BC-AD 1520: a social network analysis. Journal of Archaeological Method and Theory 22:206-247

Götz, C.M. (2008). Coastal and inland patterns of faunal exploitation in the prehispanic northern Maya lowlands. Quaternary International 191:154-169.

Graham, E. (1991). Archaeological insights into Colonial period Maya life at Tipu, Belize. In Columbian Consequences Vol. 3: The Spanish Borderlands in Pan-American Perspective (D.H. Thomas, editor). Smithsonian Institute Press, Washington, D.C., pp. 319-335.

Grimstead D.N., Reynolds, A.C., Hudson, A.M., Akins, N.J., and Betancourt, J.L. (2014). Reduced population variance in strontium isotope ratios informs domesticated turkey use at Chaco Canyon, New Mexico, USA. Journal of Archaeological Method and Theory 21:1-23.

Hall, T.A. (1999). BioEdit: a user-friendly biological sequence alignment editor and analysis program for Windows 95/98/NT. Nucleic Acids Symposium Series No. 41:98-98. 
Hamblin, N.L. (1984). Animal use by the Cozumel Maya. University of Arizona Press, Tucson.

Hammond, N. (1973). British Museum-Cambridge University Corozal Project 1973 Interim Report. Cambridge University - Centre of Latin American Studies, Cambridge.

Hansen R.D. (1990). Excavations in the Tigre Complex El Mirador, Petén, Guatemala, New World Archaeological Foundation, Provo, UT.

Hedges, R.E.M., Clement, J.G., Thomas, C.D.L., and O'Connell, T.C. (2007). Collagen turnover in the adult femoral mid-shaft: modeled from anthropogenic radiocarbon tracer measurements. American Journal of Physical Anthropology 33:808-816.

Hobson, K.A., and Clark, R.G. (1992). Assessing avian diets using stable isotopes I: turnover of ${ }^{13} \mathrm{C}$ in tissues. The Condor 94:181-188.

Hodell, D.A., Quinn, R.L., Brenner, M., and Kamenov, G. (2004). Spatial variation of strontium isotopes $\left({ }^{87} \mathrm{Sr} /{ }^{86} \mathrm{Sr}\right)$ in the Maya region: a tool for tracking ancient human migration. Journal of Archaeological Science 31:586-601.

Hoppe, K.A., Koch, P.L., and Furutani, T.T. (2003). Assessing the preservation of biogenic strontium in fossil bones and tooth enamel. International Journal of Osteoarchaeology 13: 2028.

Hurst, G.A. (1992). Foods and feeding. In: The Wild Turkey: Biology and Management (J.G. Dickson, editor). Stackpole Books, Mechanicsburg, PA, pp. 66-83.

Hwang, Y.T., Millar, J.S., and Longstaffe, F.J. (2007). Do $\delta^{15} \mathrm{~N}$ and $\delta^{13} \mathrm{C}$ values of feces reflect the isotopic composition of diets in small mammals? Canadian Journal of Zoology 85:388-396.

Kellner, C.M., and Schoeninger, M.J. (2007). A simple carbon isotope model for reconstructing prehistory human diet. American Journal of Physical Anthropology 133:1112-1127.

Koch, P.L., Tuross, N., and Fogel, M.L. (1997). The effects of sample treatment and diagenesis on the isotopic integrity of carbonate in biogenic hydroxylapatite. Journal of Archaeological Science 24:417-429.

Lapham, H.A., Feinman, G.M., and Nicholas, L.M. (2013). Animal economies in pre-Hispanic southern Mexico. In The Archaeology of Mesoamerican Animals (C.M. Götz, and K.F. Emery, editors). Lockwood Press, Atlanta, pp. 153-190.

Lee-Thorp, J.A., Sealy, J. C., and van der Merwe, N. J. (1989). Stable carbon isotope ratio differences between bone collagen and bone apatite, and their relationship to diet. Journal of Archaeological Science 16:585-99.

Lee-Thorp, J.A., and Sponheimer, M. (2003). Three case studies used to reassess the reliability of fossil bone and enamel isotope signals for paleodietary studies. Journal of Anthropological Archaeology 22:208-216.

Leopold, A. (1948). The wild turkeys of Mexico. Transactions of the $13^{\text {th }}$ North American Wildlife Conference, Wildlife Management Institute, Washington, D.C., pp. 393-400. 
Leopold, A. (1959). Wildlife of Mexico: The Game Birds and Mammals. University of California Press, Berkeley.

Liden, K., Takahashi, C. and Nelson, D.E. (1995). The effects of lipids in stable carbon isotope analysis and the effects of $\mathrm{NaOH}$ treatment on the composition of extracted bone collagen. Journal of Archaeological Science 22:321-326.

Lipe, W.D., Bocinsky, R.K., Chisholm, B.S., Lyle, R., Dove, D.M., Matson, R.G., Jarvis, E., Judd, K., and Kemp, B.M. (2016). Cultural and genetic contexts for early turkey domestication in the northern Southwest. American Antiquity 81:97-113.

Makarewicz, C., and Tuross, N. (2012). Finding fodder and tracking transhumance: isotopic detection of goat domestication processes in the Near East. Current Anthropology 53:495-505.

Marino, B.D., and McElroy, M.B. (1991). Isotopic composition of atmospheric $\mathrm{CO}_{2}$ inferred from carbon in C4 plant cellulose. Nature 349:127-131.

Márquez-Olivas, M., García Moya, E., González-Rebeles Islas, C., and Tarango Arámbula, L.A. (2005). Diet composition of reintroduced wild turkey (Meleagris gallopavo) in "Sierra Fria", Aguascalientes, Mexico. Veterinaria México 36:395-409.

Masson, M.A., and Peraza Lope, C. (2008). Animal use at the Postclassic Maya center of Mayapán. Quaternary International 191:170-183.

McCaffery, H., Tykot, R.H., Gore, K.D., and DeBoer, B.R. (2014). Stable isotope analysis of turkey (Meleagris gallopavo) diet from Pueblo II and Pueblo III sites, Middle San Juan region, northwest New Mexico. American Antiquity 79:337-352.

McKusick, C.R. (1986). Southwest Indian Turkeys: Prehistory and Comparative Osteology. Southwest Birds Laboratory, Globe, AZ.

McKusick, C.R. (2001). Southwest Birds of Sacrifice. Arizona Archaeologist No. 31, Arizona Archaeological Society, Phoenix.

McRoberts, J.T. (2014). Investigations into the Ecology and Management of Ocellated Turkeys in Campeche, Mexico. Unpublished Ph.D. dissertation, Department of Wildlife Science, Texas Tech University.

Minagawa, M., Matsui, A., and Ishiguro, N. (2005). Patterns of prehistoric boar Sus scrofa domestication, and inter-islands pig trading across the East China Sea, as determined by carbon and nitrogen isotope analysis. Chemical Geology 218:91-102

Monteagudo, L.V., Avellanet, R., Azon, R., and Tejedor, M.T. (2013). Mitochondrial DNA analysis in two heritage European breeds confirms Mesoamerican origin and low genetic variability of domestic turkey. Animal Genetics 44:786.

Morales Puente, P., Cienfuegos Alvarado, E., Manzanilla Naim, L.R., and Otero Trujano, F.J. (2012). Estudio de la paleodieta empleando isótopos estables de los elementos carbon, oxígeno y nitrógeno en restos humanos de fauna encontrados en el barrio teotihuacano de Teopancazco. In 
Estudios Aqueométricos del Centro de Barrio de Teopancazco en Teotihuacan (L.R. Manzanilla, editor). Universidad Nacional Autónoma de México, Mexico City, pp. 247-423.

Mulligan, C. (2005). Isolation and analysis of DNA from archaeological, clinical and natural history specimens. Methods in Enzymology 395: 87-103.

Munro, N.D. (2006). The role of turkeys in the Southwest. In The handbook of North American Indians, volume 3, environment, origins and populations (W.C. Sturtevant and D.H. Ubelaker, editors). Smithsonian Institution, Washington, DC, pp. 463-470.

Munro, N.D. (2011). Domestication of the turkey in the American Southwest. In The subsistence economies of indigenous North American societies: A handbook (B.D. Smith, editor). Smithsonian Institution Scholarly Press, Washington, D.C., pp. 543-555.

Newbold, B.A., Janetski, J.C., Bodily, M.L., and Yoder, D.T. (2012). Early Holocene turkey (Meleagris gallopavo) remains from southern Utah: implications for the origins of the Puebloan domestic turkeys. KIVA: The Journal of Southwestern Anthropology and History 78:37-60.

Nielsen-Marsh, C.M., and Hedges, R.E.M. (2000). Patterns of diagenesis in bone I: the effects of site environments. Journal of Archaeological Science 27:1139-1150.

Noe-Nygaard, N., Price, T.D., and Hede, S.U. (2005). Diet of aurochs and early cattle in southern Scandinavia: evidence from ${ }^{15} \mathrm{~N}$ and ${ }^{13} \mathrm{C}$ stable isotopes. Journal of Archaeological Science 32: 855-871.

Pendergast, D.M. (1991). The southern Maya Lowlands contact experience: the view from Lamanai, Belize. In Columbian Consequences Vol. 3: The Spanish Borderlands in PanAmerican Perspective (D.H. Thomas, editor). Smithsonian Institute Press, Washington, D.C., pp. 337-354.

Pohl, M.D. (1977). Hunting in the Maya village of San Antonio, Rio Hondo, Orange Walk District, Belize. Journal of Belizean Affairs 5:52-63.

Pohl, M.D., and Feldman, L.H. (1982). The traditional role of women and animals in the lowland Maya economy. In Maya subsistence: Studies in memory of Dennis E. Puleston (K.V. Flannery, editor). Academic Press, New York, pp. 295-311.

Pollock, H.E.D., and Ray, C.E. (1957). Notes on vertebrate animal remains from Mayapan. Carnegie Institution of Washington, Current Reports, 41:633-656.

Price, T.D. (2006). Early African diaspora in colonial Campeche, Mexico: strontium isotopic evidence. American Journal of Physical Anthropology 130:485-490.

Price, T.D., Blitz, J., Burton, J., Ezzo, J.A. (1992). Diagenesis in prehistoric bone: problems and solutions. Journal of Archaeological Science 19:513-529.

Price, T.D., Burton, J.H., Fullager, P.D., Wright, L.E., Buikstra, J.E., and Tiesler, V. (2008). Strontium isotopes and the study of human mobility in ancient Mesoamerica. Latin American Antiquity 19:167-180. 
Price, T.D., Burton, J.H., Sharer, R.J., Buikstra, J.E., Wright, L.E., Traxler, L.P., and Miller, K.A. (2010). Kings and commoners at Copan: isotopic evidence for origins and movement in the Classic Maya period. Journal of Anthropological Archaeology 29:15-32.

Price, T.D., Manzanilla, L., and Middleton, W.D. (2000). Immigration and the ancient city of Teotihuacan in Mexico: a study using strontium isotope ratios in human bone and teeth. Journal of Archaeological Science 27:903-913.

Rawlings, T.A., and Driver, J.C. (2010). Paleodiet of domestic turkey, Shields Pueblo (5MT3807), Colorado: Isotopic Analysis and its implications for care of a household domesticate. Journal of Archaeological Science 37:2433-2441.

Schoeninger, M.J., and DeNiro, M.J. (1984). Nitrogen and carbon isotopic composition of bone collagen from marine and terrestrial animals. Geochimica et Cosmochimica Acta 48:625-639.

Sharer, R.J. (2004). External interaction at Early Classic Copan. In Understanding Early Classic Copan (E.E. Bell, M.A. Canuto, and R.J. Sharer, editors). University of Pennsylvania Museum, Philadelphia, pp. 297-317.

Sharp, Z.D., Atudorei, V., and Furrer, H. (2000). The effect of diagenesis on oxygen isotope ratios of biogenic phosphates. American Journal of Science 300:222-237.

Sillen, A., and Sealy, J.C., 1995. Diagenesis of strontium in fossil bone: a reconsideration of Nelson et al. (1986). Journal of Archaeological Science 22:313-320.

Smith, B.N. and Epstein, S. (1971). Two categories of ${ }^{13} \mathrm{C} /{ }^{12} \mathrm{C}$ ratios for higher plants. Plant Physiology 47:380-384.

Somerville, A.D. (2015). Leporids, Landscapes, and Social-Environmental Dynamics in Arid North America: Stable Isotope Analysis of Rabbit and Hare Bones from Modern and Archaeological Sites. Unpublished Ph.D. dissertation, Department of Anthropology, University of California, San Diego.

Someville, A.D., Nelson, B.A., and Knusdon, K.J. (2010). Isotopic investigation of pre-Hispanic macaw breeding in Northwest Mexico. Journal of Anthropological Archaeology 29:125-135.

Speller, C.F., Kemp, B.M., Wyatt, S.D., Monroe, C., Lipe, W.D., Arndt, U.M., and Yang, D.Y. (2010). Ancient mitochondrial DNA analysis reveals complexity of indigenous North American turkey domestication. Proceedings of the National Academy of Science 107:2807-2812.

Steadman, DW. (1980). A review of the osteology and paleontology of turkeys (Aves: Meleagridae). Contribution of the Science and Natural History Museum of Los Angeles County California 330:131-207.

Stearns, B.D. (2010). Diet Reconstruction of Wild Rio-Grande Turkey of Central Utah Using Stable Isotope Analysis. Unpublished MS Thesis, Department of Plant and Wildlife Sciences, Brigham Young University, Provo, UT. 
Sugiyama, N. Somerville, A.D., and Schoeninger, M.J. (2015). Stable isotopes and zooarchaeology at Teotihuacan, Mexico reveal earliest evidence of wild carnivore management in Mesoamerica. PLoS One. DOI:10.1371/journal.pone.0135635.

Sutoh, M., Koyama, T., and Yoneyama, T. (1987). Variations of natural ${ }^{15} \mathrm{~N}$ abundances in the tissues and digesta of domestic animals. Radioisotopes 36:74-77. PMID:3575790.

Thornton, E.K. (2011). Reconstructing ancient Maya animal trade through strontium isotope $\left({ }^{87} \mathrm{Sr} /{ }^{86} \mathrm{Sr}\right)$ analysis. Journal of Archaeological Science 38:3254-3263.

Thornton, E.K., Emery, K.F., Steadman, D.W., Speller, C., Matheny, R., and Yang, D. (2012). Earliest Mexican turkeys (Meleagris gallopavo) in the Maya region: implications for preHispanic animal trade and the timing of turkey domestication, PLoS One 7(8), e42630. doi:10.1371/journal.pone.0042630.

Thornton, E.K. and Emery, K.F. (2015). The uncertain origins of the Mesoamerican turkey domestication. Journal of Archaeological Method and Theory, published on-line Dec. 2015, DOI 10.1007/s10816-015-9269-4.

Tieszen, L.L. \& Fagre, T. (1993). Effect of diet quality and composition on the isotopic composition of respiratory $\mathrm{CO}_{2}$, bone collagen, bioapatite, and soft tissues. In Prehistoric Human Bone-Archaeology at the Molecular Level ((J.B. Lambert and G. Grupe, editors). SpringerVerlag, Berlin, pp. 121-155.

Tykot, R.H., van der Merwe, N.J., and Hammond, N. (1996). Stable isotope analysis of bone collagen and apatite in the reconstruction of human diet: a case study from Cuello, Belize. In Archaeological Chemistry: Organic, Inorganic, and Biochemical Analysis (M.V. Orna, editor). ACS Symposium Series 625, American Chemical Society, Washington, D.C., pp. 355-365.

Valadez Azúa, R. (1993). Macrofósiles faunísticos. In Anatomía de un conjunto residencial Teotihuacano en Oztoyahualco, Mexico (L. Manzanilla, editor). Universidad Nacional Autónoma de México, Instituto de Investigaciones, Mexico City, pp. 729-813.

Valadez Azúa, R. (2003). La Domesticación Animal. Universidad Nacional Autónoma de Mexico, Instituto de Investigaciones Antropológicas, Mexico City.

Valadez Azúa, R., and Arrellín Rosas, R. (2000). La domesticación de animales. In Historia antigua de Mexico: Volumen 1 (L. Manzanilla, and L. López Luján, editors). Instituto Nacional de Antropología e Historia, Mexico City, pp. 379-334.

Valadez Azúa, R., Rodriguez Galicia, B., Manzanilla Naim, L., and Tejada, S. (2006). Dog-wolf hybrid biotype reconstruction from the archaeological site of Teotihuacan in prehispanic central Mexico. In Dogs and People in Social, Working, Economic or Symbolic Interaction. Proceedings of the $9^{\text {th }}$ ICAZ Conference, Durham, England 2002 (L. Snyder, and E. Moore, editors), Oxbow, Oxford, pp. 121-131.

Valadez Azúa, R., Blanco Padilla, A., Rodríguez Galicia, B., and Pérez Roldán, G. (2013). The dog in the Mexican archaeozoological record. In The Archaeology of Mesoamerican Animals (C.M. Gotz and K.F. Emery, editors), Lockwood Press, Atlanta, pp. 557-582. 
Van der Merwe, N.J. (1982). Carbon isotopes, photosynthesis, and archaeology. American Scientist 70: 209-215.

van der Merwe, N.J., and Medina, E. (1991). The canopy effect, carbon isotope ratios and foodwebs in Amazonia. Journal of Archaeological Science 18:249-259.

Vander Zanden M.J., Clayton, M.K., Moody, E.K., Solomon, C.T., and Weidel, B.C. (2015). Stable isotope turnover and half-life in animal tissues: A literature synthesis. PLoS ONE 10(1): e0116182. doi:10.1371/journal.pone.0116182.

van Klinken, G.J. (1999). Bone collagen quality indicators for paleodietary and radiocarbon measurements. Journal of Archaeological Science 26:697-695.

White, C.D., Pohl, M.D., Schwarcz, H.P., and Longstaffe, F.J., (2001). Isotopic evidence for Maya patterns of deer and dog use at Preclassic Colha. Journal of Archaeological Science 28:89-107.

White, C.D., M. Pohl, H.P. Schwarcz, and FJ Longstaffe (2004). Feast, field, and forest: deer and dog diets at Lagartero, Tikal and, Copan. In Maya Zooarchaeology: New Directions in Method and Theory (K.F. Emery, editor), Cotsen Institute of Archaeology, Monograph 51, University of California, Los Angeles, pp. 141-158.

White, C.D., Price, T.D., and Longstaffe, F. (2007). Residential histories of human sacrifices at the Moon Pyramid, Teotihuacan. Ancient Mesoamerica 18:159-172.

Wing, E.S., and Steadman, D. (1980). Vertebrate faunal remains from Dzibilchaltun. In Excavations at Dzibilchaltun, Yucatan, Mexico (E.W. Andrews IV, and E.W. Andrews V, editors), Middle American Research Institute, Tulane University, New Orleans, pp. 326-331.

Wright, L.E. (2005a). Identifying immigrants to Tikal, Guatemala: defining local variability in strontium isotope ratios of human tooth enamel. Journal of Archaeological Science 32:555-566.

(2005b). In search of Yax Nuun Ayiin I: revisiting the Tikal project's Burial 10. Ancient Mesoamerica 16:89-100.

Wright, L.E. (2006). Diet, Health, and Status among the Pasion Maya: a Reappraisal of the Collapse. Vanderbilt Institute of Mesoamerican Archaeology Series, Volume 2 (A. Demarest, series editor), Vanderbilt University, Nashville.

Williams, L.E., Baur, E.H., and Eichholz, N.F., (2010). The Ocellated Turkey in the Land of the Maya. Real Turkeys Publishers, Cedar Key, Florida.

Yang D.Y., Eng, B., Waye, J.S., Dudar, J.C., and Saunders, S.R. (1998). Improved DNA extraction from ancient bones using silica-based spin columns. American Journal of Physical Anthropology 105:539-543. 